\title{
Mechanisms of basin contraction and reactivation in the basement-involved Malargüe fold-and-thrust belt, Central Andes $\left(34-36^{\circ} \mathrm{S}\right)$
}

\author{
M. BRANELLEC* $\dagger$, B. NIVIĖRE* J.-P. CALLOT* \& J.-C. RINGENBACHł \\ *Université de Pau et des Pays de l'Adour, Laboratoires des Fluides Complexes et Leurs Réservoirs, Equipes \\ Geosciences, CNRS UMR 5150, Avenue de L'université, Pau, France \\ $\ddagger$ Total SA, Centre Scientifique et Technique Jean Féger, Avenue Larribau, Pau 64000, France
}

(Received 10 December 2015; accepted 19 March 2016; first published online 28 July 2016)

\begin{abstract}
We have conducted a structural study of both the basement-involved Malargüe fold-andthrust belt (MFTB) and the active San Rafael Block (SRB), which are located in the Central Andes at latitude $34-36^{\circ} \mathrm{S}$. Based on several field examples located both in the inner and frontal part of belt and from the distal foreland zone, we focus on the relationships between basement and cover deformation with respect to the known palaeogeography and structural inheritance. In several zones, we point out similarities in the structural and sedimentary responses to Andean shortening. The recent morphologic response has also been investigated through the analysis of active deformation along the eastern border of the SRB. We show that these structural and sedimentary processes are continuous in time and space since they can be applied in the various parts of the fold belt and also at different stages of fold-and-thrust-belt building as well. Finally, we propose the illustration of those mechanisms by complete cross-section along the Rio Grande valley and a possible kinematic scenario of deformation propagation.
\end{abstract}

Keywords: tectonics, cross-section, Neuquén Basin, structural inheritance, kinematics.

\section{Introduction}

The inversion of extensional sedimentary basins has received much attention during the last three decades due to the need to understand the role of pre-existing faults and their related anisotropies as preferential structures accommodating shortening in the upper crust (see for example the detailed review by Bonini, Sani \& Antonielli, 2012). During basin inversion pre-existing faults may concentrate stress and localize future neoformed thrust, or may be reactivated showing reversal movement from extension to reverse motion. Basin contraction/fault inversion has usually been studied, focusing on (1) the geological conditions required to produce fault inversion, by exploring the role of the main factors governing fault reactivation susceptibility such as fluid pressure, fault weakness, fault steepness, angle of applied shortening, sediment loading, geometry and strength of a basal ductile layer during an inversion; and (2) the distribution of deformation at the basin scale, associated structural styles resulting from fault inversion and their impact in terms of thermal history within sedimentary basins, as well as hydrocarbon maturation and trapping.

As for many locations around the world, the Neuquén Basin, which is located in southern Central Andes, underwent a complex and polyphased geological history, explaining why it is a well-suited place to study reactiv-

$\nmid$ Author for correspondence: matthieu.branellec@gmail.com ation/inversion mechanisms and the related geometries. Indeed, an extensional tectonic regime prevailed from Late Triassic times, opening small and isolated synrift troughs that merged into a single large sag basin by Toarcian times. With the opening of the South Atlantic Ocean, a major plate reorganization took place by middle Cretaceous times leading to shortening conditions in the back-arc area and the contractional reactivation of the basin (Manceda \& Figueroa, 1995; Vergani et al. 1995; Howell et al. 2005). The present study focuses on the Malargüe fold-and-thrust belt (MFTB) located between $34^{\circ} \mathrm{S}$ and $37^{\circ} \mathrm{S}$ which lies on the northern part of the Neuquén Basin (Fig. 1a; Kozlowski, Manceda \& Ramos, 1993). We also include in this work the distal San Rafael Block (SRB), a basementinvolved morpho-structural unit located $100 \mathrm{~km}$ east of the orogenic front of the Principal Cordillera (Fig. 1b) known to have recorded the Miocene shortening (Branellec et al. 2015a).

The importance given to the extensional structural inheritance as a key parameter at the time of thrusting remains disputed in the MFTB. Some authors suggest that the rift-related inherited structural and sedimentological anisotropies exert a strong structural control on Andean structures (e.g. Ramos, Cegarra and Cristallini, 1996; Giambiagi et al. 2008; Mescua et al. 2014). According to these studies, early normal faults can be entirely or partially reactivated (i.e. as a shortcut fault). They demonstrated that the orientation of 

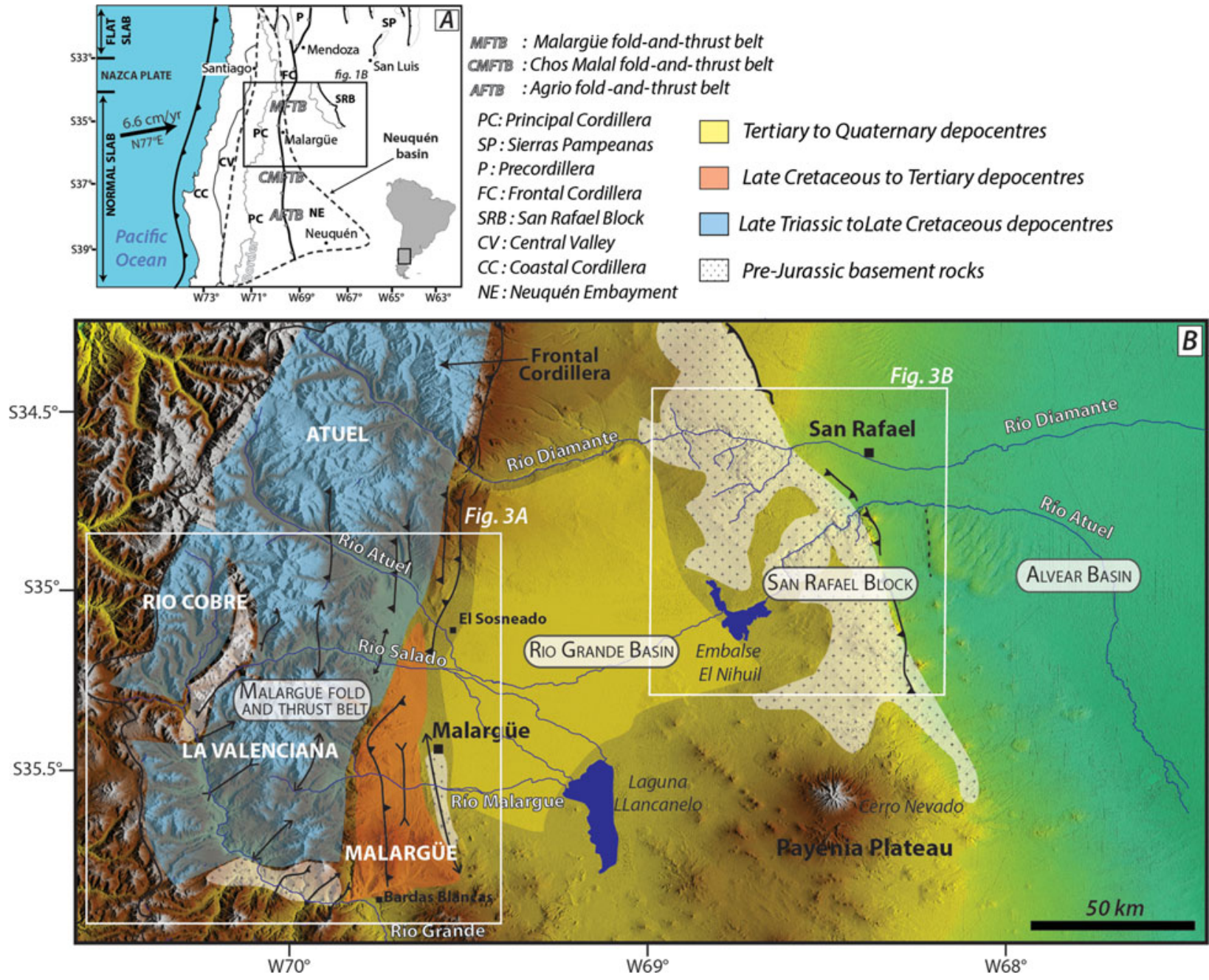

Figure 1. (a) Large-scale geodynamical setting between $32^{\circ} \mathrm{S}$ and $40^{\circ} \mathrm{S}$, showing the main morphostructural units of the Neuquén basin. (b) ASTER GDEM of the study area highlighting the various structural domains between $34^{\circ} \mathrm{S}$ and $36^{\circ} \mathrm{S}$ : the Malargüe fold-and-thrust belt, the Rio Grande Basin, the San Rafael Block and the Alvear Basin.

these pre-existing structures, the physico-mechanical characteristics of fault planes and the Andean stress field are compatible with fault inversion/reactivation (Mescua \& Giambiagi, 2012). Numerical models support possible reactivations in the MFTB due to the high obliquity of early half-grabens with respect to the Andean stress field (Yagupsky et al. 2008). Conversely, others authors have assigned a minor role to fault inversion/reactivation as it is not well documented. They considered that a large majority of Andean structures are low-angle newly formed thrusts that have emplaced independently of any structural control (Dimieri \& Nullo, 1993; Turienzo \& Dimieri, 2005; Dimieri \& Turienzo, 2012; Turienzo et al. 2012). These authors however recognize that fault inversion is theoretically feasible in some restricted places, but generally (1) it cannot account for the shortening calculated in the cover; and (2) does not properly balance the basement deformation.

Basin shortening is likely to have been the origin of a large spectrum of reactivated as well as newly formed structures deforming the sedimentary column. Never- theless, based on three field examples chosen both in the internal and frontal areas of the Malargüe fold-andthrust belt as well as along the distal eastern border of the SRB, we put forward a simple recurrent reactivation scheme that applies from Late Cretaceous time to the present. Given their position in the Andean system, the various investigated geological features that recorded tectonic inversion/reactivation offer the opportunity to study: (1) the Andean deformational pattern throughout the MFTB; (2) the characteristics of the related synorogenic sedimentation in the preserved frontal zone; and (3) the geomorphological response to shortening along the SRB, which is analysed in detail by Branellec et al. (2016).

\section{Three scenarios of graben inversion}

We aim to evaluate the role of the extensional inheritance during Andean shortening structures, and more particularly the role of the position and orientation of early basement highs and depocentres. Here we will not discuss the contractional mechanisms at basin scale; 


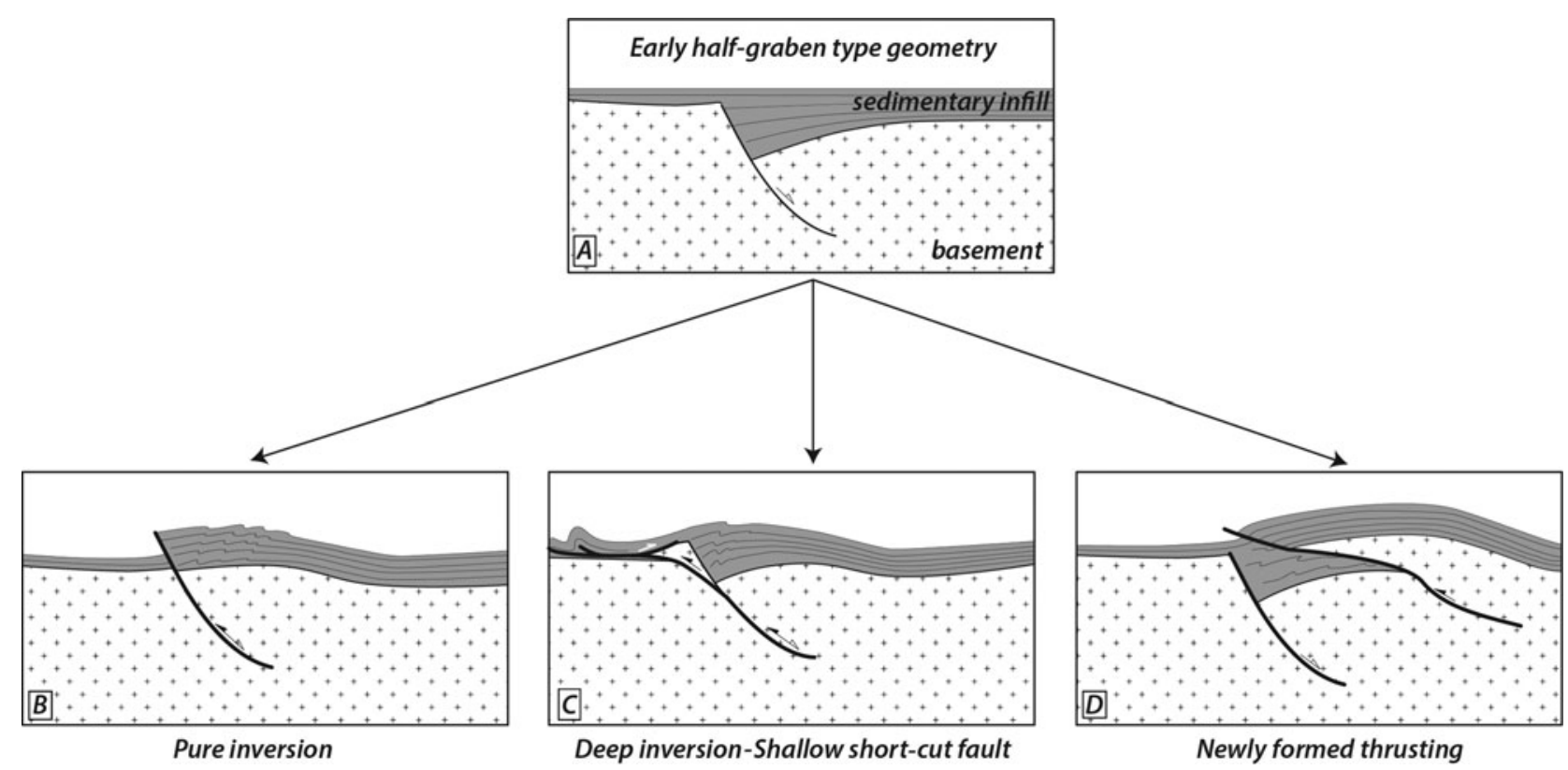

Figure 2. Three end-member scenarios of half-graben contraction based on Bonini, Sani \& Antonielli (2012). See text for further details.

rather, we focus on the expression of these processes at local scale.

Starting from initial half-graben geometry and based on the compilation of conceptual models available in Bonini, Sani \& Antonielli (2012), we selected three end-member scenarios of basin contraction (Fig. 2). Shortening may be accommodated by reactivation of former extensional structures or by the creation of newly formed structures (Fig. 2b-d). the 'pure inversion' case presented in Figure $2 b$ characterizes the total or partial recovering of the initial pre-rift geometry of the top basement horizon, and the extrusion of the halfgraben infill through complete activation of the former normal fault. This situation usually requires high obliquity of the applied shortening (e.g. Brun \& Nalpas, 1996). Nevertheless, even for orthogonal shortening, fault reactivation may be possible due to high fluid pressure. Among others, fault steepness and weakness are important parameters that could influence fault reactivation. In certain cases, the normal fault can be partially inverted at depth due to favourable fault plane dip $\left(<40^{\circ}\right)$ giving rise first to synrift material extrusion. Subsequently, as the normal fault plane steepens upwards, inversion is no longer possible and a newly formed short-cut fault develops, lifting the border of the former half-graben (we label it the 'short-cut case' in Fig. 2c). In this case, the short-cut fault is likely to propagate and die out within the cover, producing thinskinned deformation. In the case of Figure $2 \mathrm{~d}$, the shortening may be accommodated by purely newly formed thrust characterized by ramps and flat geometries in both basement and cover, controlled by the mechanical architecture of the sedimentary cover. In this case thrust location may not depend on the structural inheritance (Fig. 2c) but will follow the mechanical anisotropies, controlled by the basement petrological and thermal inheritances, and by the cover mechanical architecture.

To summarize, two classes of thrusting processes can occur in rift-related basins affected by shortening. First, inheritance-related thrusting is governed by strain localization along pre-existing half-graben borders, giving rise to different sketches of basement/cover interactions (Fig. 2b, c). In those cases the impact of the initial riftrelated anisotropies and their orientation with respect to the shortening direction are key parameters to be taken into account at the time of contraction. Second, newly formed thrusts can occur; since structural inheritance does not influence their location, the main parameters that are likely to constrain their geometry are the architecture and rheology of the sedimentary column (Fig. 2d).

\section{Geological framework}

The Neuquén Basin has a triangular shape and extends from the Chilean side of the Principal Cordillera to the west, as far as the Rio Grande Basin eastwards (Fig. 1a, b).

From Proterozoic time until the present day, three main stages have occurred: (1) during Palaeozoic - Late Triassic time, several allochthonous terranes collided with the western margin of Gondwana and widespread subduction-related magmatic bodies were emplaced; (2) an extensional tectonic regime prevailed during late Permian - Early Cretaceous time; before (3) the building of the Andes from Late Cretaceous time to the present day, characterizing the fold-and-thrust belt stage (Kay et al. 1989; Kozlowski, Manceda \& Ramos, 1993; Franzese \& Spalletti, 2001; Giambiagi et al. 2009b). 

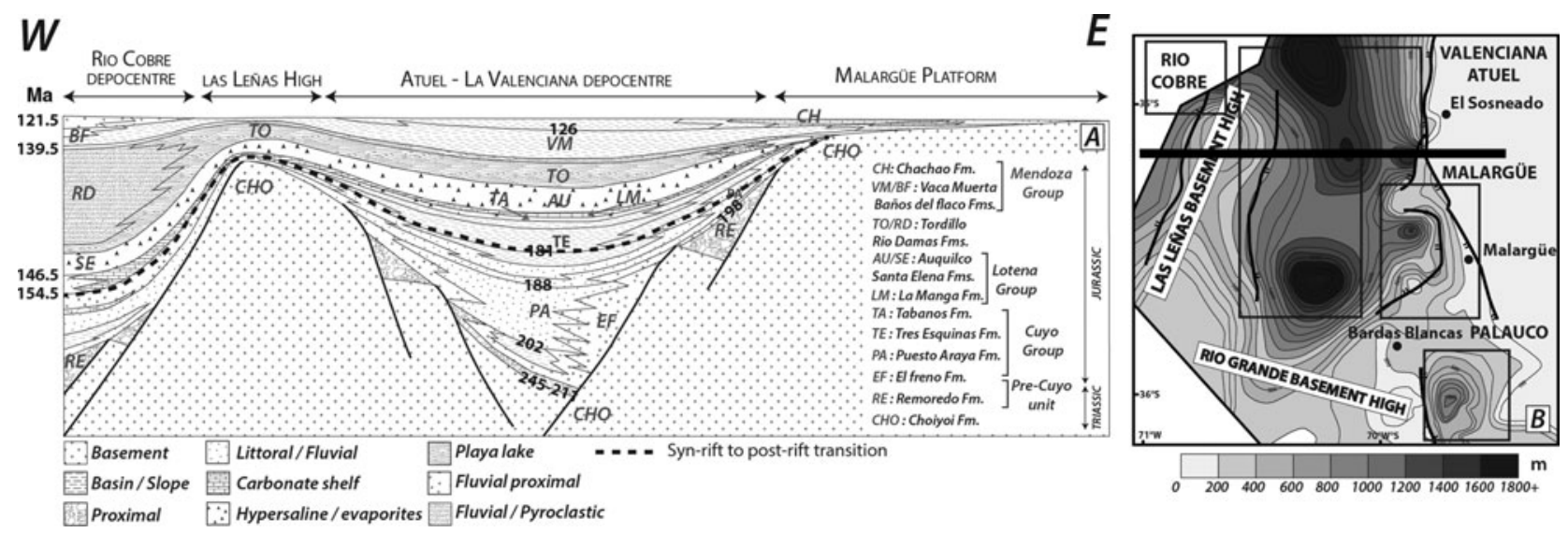

Figure 3. (a) Schematic E-W-aligned cross-section showing the half-graben geometry of the Jurassic extensional basin and the associated filling sequences up to the Vaca Muerta Formation. (b) Palinspatically restored isopach map on top of the Lower-Middle Jurassic beds showing several depocentres separated by intervening highs. Modified after Manceda \& Figueroa (1995) and Legaretta \& Uliana (1996).

\section{3.a. Extensional stage}

The Neuquén Basin started to develop during late Permian - Early Triassic time, when gravitational collapserelated extension triggered the aperture of narrow NW-SE-trending half-grabens (Uliana et al. 1989; Legarreta et al. 1993; Legarreta \& Uliana, 1996; Franzese \& Spalletti, 2001). Basement is assimilated to PermoTriassic pre-rift units which are mainly represented by the Choiyoi Group rocks, consisting of magmatic and volcaniclastic rocks (Llambías, Quenardelle \& Montenegro, 2003; Kleiman \& Japas, 2009; Fig. 4). As tectonic subsidence developed, the volcaniclastic and continental-restricted Pre-Cuyo unit began to accumulate in isolated troughs (Remoredo and El Fresno formations; Figs 3, 4). The transition from continental/shelf environment (El Fresno and Puesto Araya formations) to basin (Tres Esquinas shales) marks the end of the synrift phase (Figs 3,4$)$ by Toarcian times and the beginning of the sagging phase. Starting from Middle Jurassic time onwards a large sag basin developed as a result of the coalescence of the various depocentres, leading to the sedimentation of the upper Cuyo, Lotena and Mendoza groups. Relative changes in sea level controlled the sedimentation pattern, which was characterized by the alternation of clastics (e.g. Lotena and Tabanos formations), carbonates (e.g. Calabozo and La Manga formations) and evaporites (e.g. Auquilco and Huitrin formations) until middle - Late Cretaceous times (Legarreta \& Uliana, 1996).

The thickness map of the Late Triassic - Early Jurassic infill of the MFTB (Fig. 3a) provided by Manceda \& Figueroa (1995) highlights the geometry of the several half-grabens and the existence of two structural highs. The $40 \mathrm{~km}$ long NNE-SSW-trending Las Leñas basement high and the E-W-trending Rio Grande delimit four depocentres (Fig. 3b). Isopachs show that these basins are asymmetric and bounded to the east by master normal faults (Manceda \& Figueroa, 1995). Figure $3 \mathrm{~b}$ depicts an E-W-aligned cross-section showing the initial extensional geometry north of Malargüe city. To the west, the Rio Cobre depocentre contains at least $6000 \mathrm{~m}$ of Mesozoic series and is limited to the east by the Las Leñas basement high, comprising basement pre-rift rocks (Mescua et al. 2014; Fig. 3). In the Valenciana/Atuel depocentre, which lies east of this basement block, the thickness of the Lower Jurassic succession may exceed $1800 \mathrm{~m}$. This depocentre is delimited to the south by the Rio Grande high. The easternmost Malargüe depocentre is smaller than previous depocentres. It is bounded to the east by the Malargüe platform (Fig. 3a) and consists of two half-grabens limited by $\mathrm{W}$-facing normal faults. The easternmost normal fault is a major structure that runs from south of Malargüe to north of the Sosneado village, and represents the eastwards termination of the extensional basin (Manceda \& Figueroa, 1995).

\section{3.b. Contractional stage}

The MFTB underwent three main shortening pulses during Late Cretaceous time to present, known as the Peruvian, Incaic and Quechua phases (Cobbold \& Rossello, 2003; Branellec et al. 2015b). Recent results by Folguera et al. (2015) demonstrated that two main exhumation events occurred during 75-55 Ma and during 15-8 Ma. As stated in Section 1, the contractional geometries and way by which the intracratonic basin was reactivated remains under debate. There is however good agreement in recognizing the coexistence of both thick-skinned and thin-skinned deformation in the MFTB (Giambiagi et al. 2008, 2009a; Ramos et al. 2014). Since deep-seated thrusting occurred in basement rocks, it is likely to generate surficial thinskinned deformation as several efficient sedimentary décollement levels may enable the upwards transfer of the shortening into the Mesozoic cover. The geological map illustrates this process if we assume that kilometrescale folds (in red in Fig. 5a) are likely to be produced by deep-seated thrusting, whereas hundred-metre-scale 


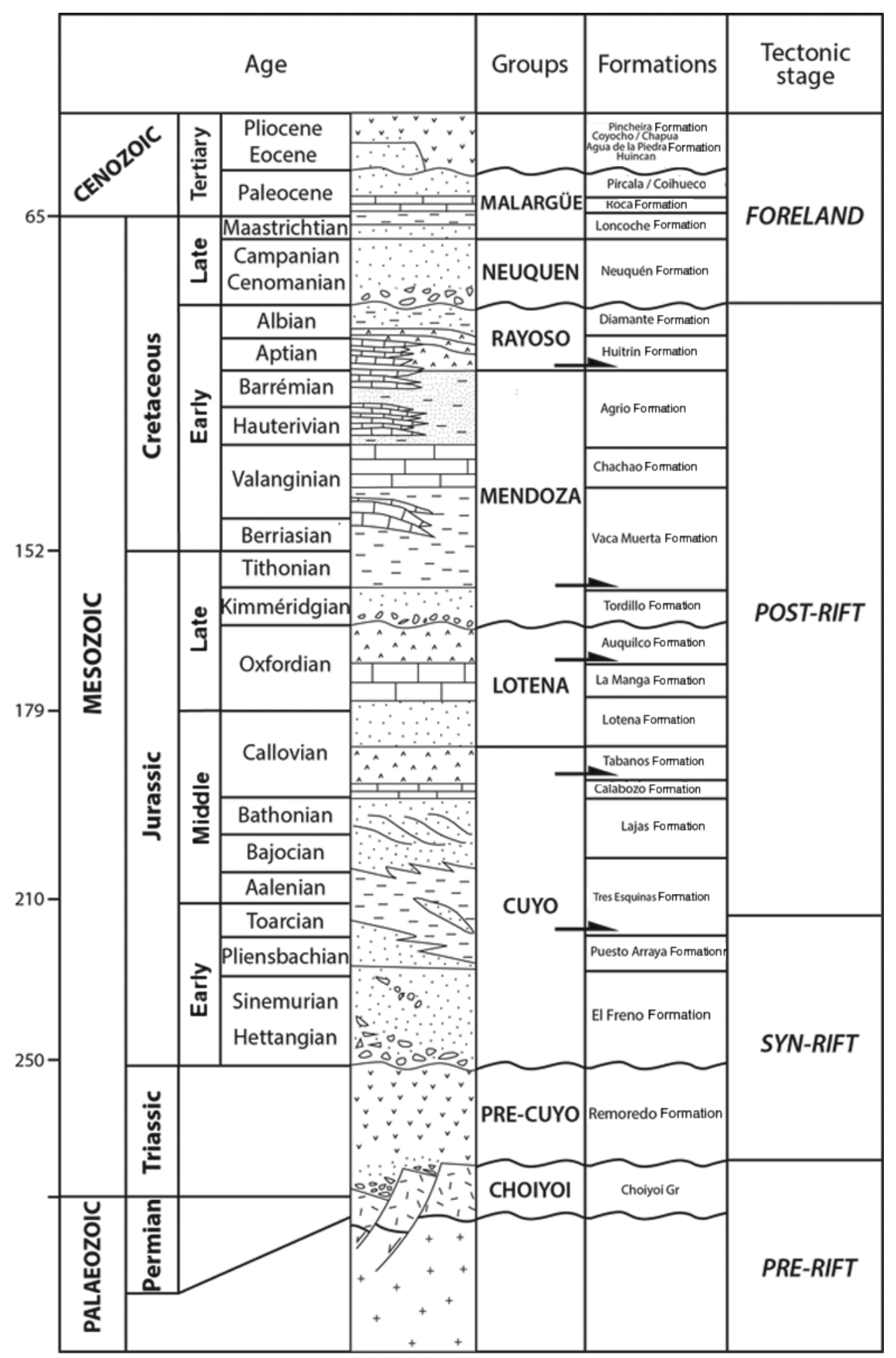

Figure 4. Simplified stratigraphic column of the various sedimentary units of the northern Neuquén basin, modified after Manceda \& Figueroa (1995).

structures (in blue in Fig. 5a) results probably from shallower décollements activation.

Another striking point of the geological map is the existence of the Las Leñas and Rio Grande highs in the present-day MFTB (Fig. 5a). These structural reliefs are still separating the various shortened half-grabens, enabling us to infer that the Andean tectonic trans- port is low and that the crustal deformation potentially mimics the Mesozoic extensional fabric. Basement rocks are also encountered in the frontal part of the belt immediately south of Malargüe in the core of the frontal anticline (Fig. 5a). The Triassic - Early Jurassic synrift deposits are mainly located in the vicinity of basement outcrops and north of La Valenciana 


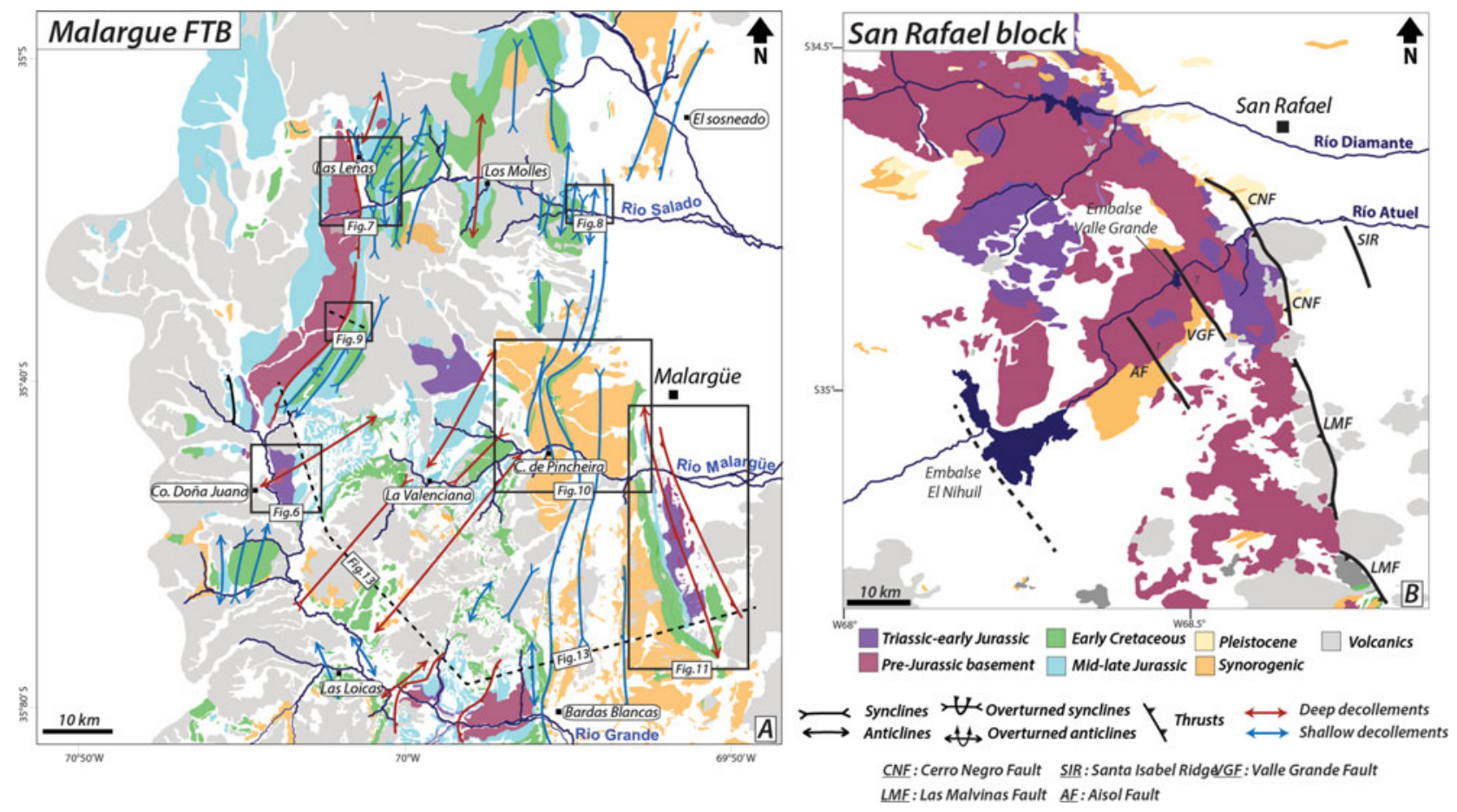

Figure 5. (a) Geological map of the Malargüe fold-and-thrust belt modified from Gonzalez \& Freije (unpub. data), courtesy Total Austral. (b) Geological map of the San Rafael Block modified from Sepulveda et al. (2000).

locality (Fig. 5a). The Middle-Late Jurassic - Late Cretaceous post-rift rocks (from the upper Cuyo to the Rayoso groups) are ubiquitously represented in the area. The Late Cretaceous synorogenic strata (Neuquén and Malargüe groups) are mostly restricted to the west of Malargüe city. They result from the exhumation of the inner parts of the MFTB, the erosion products of which have been transported and stored into the Malargüe depocentre that was later subjected to shortening. Several Neuquén Group outcrops were similarly reported in the westernmost Rio Cobre depocentre, as well as in the core of several syncline folds (e.g. north of Los Molles; Fig. 2).

\section{3.c. The San Rafael Block}

The San Rafael Block (SRB; Figs 1, 5) is separated from the MFTB front by the $1500 \mathrm{~m}$ high and $2500 \mathrm{~m}$ thick Rio Grande intramontane basin. East of the SRB lies the Alvear Basin (AB), which currently represents the Andean foreland sensu stricto (Fig. 1) and comprises Greenvillian-aged rocks, Ordovician carbonates and ultramafic bodies, and Siluro-Devonian deposits. All these rocks are interpreted as being related to the continental collision along the western Gondwana margin (Haller \& Ramos, 1984; Ramos et al. 1984; Cingolani et al. 2005). The subsequent Gondwana orogenic cycle is characterized by foreland-related sedimentation of Carboniferous-Permian-aged rocks, known as the El Imperial Formation, followed by volcanics and sedimentary units of the Choiyoi Group. At the end of the Gondwana orogeny, the generalized extension resulted in the deposition of rift-related rocks in halfgrabens known as the Puesto Viejo Formation (upper Choiyoi Group), as well as the intrusion of several magmatic bodies (Kleiman \& Japas, 2009). Beginning during Late Triassic times, the SRB permanently acted as a structural relief until Miocene time (Kleiman \& Japas, 2009) and therefore did not record the sag phase in the same way as the MFTB. This implies that the post-riftrelated sedimentary inheritance and the potential local disharmony due to the thick Mesozoic cover and its internal décollement levels are absent from the SRB. In others words, the rheological control of the sedimentary column appears to be subordinated to the general half-graben geometry and therefore to the basement inheritance.

The SRB has been involved in Andean shortening since Miocene times. According to some authors, shortening began to prevail in response to Nazca slab shallowing during middle-late Miocene times (Kay et al. 2006; Ramos \& Kay, 2006). In the companion paper (Branellec et al. 2016) we analyse several active faults located along the east SRB and demonstrate that they can potentially be responsible for destructive earthquakes.

\section{Examples of contractional geometries in the MFTB}

\section{4.a. The eastern border of the Las Leñas High}

The Las Leñas High (LLH) has long been recognized as a palaeohorst, separating the initial western Rio Cobre depocentre (Manceda \& Figueroa, 1995; 

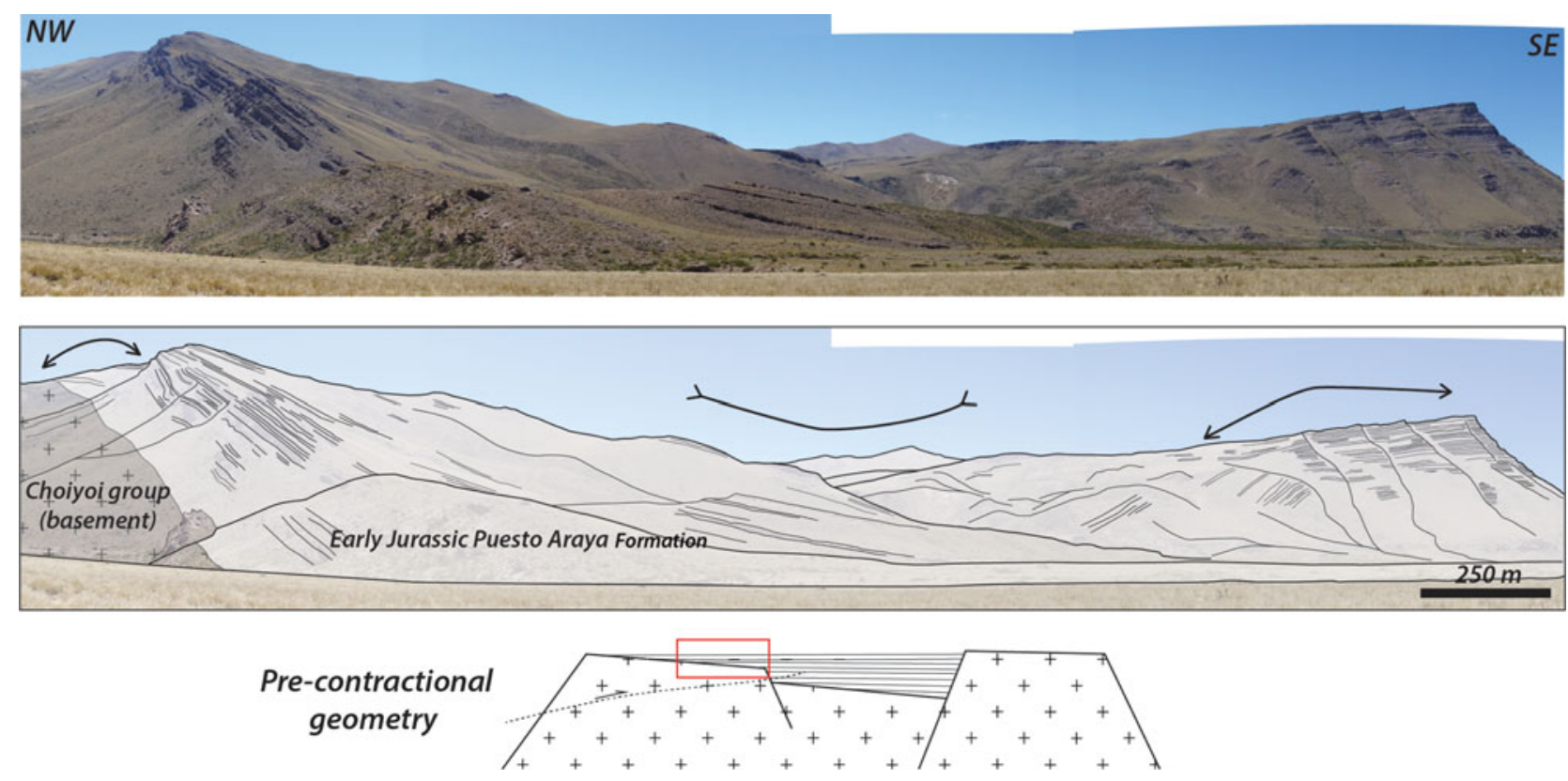

Figure 6. (Colour online) Field picture emphasizing the relationship between basement and cover deformation at the southern termination of the Las Leñas High.

Mescua et al. 2014) from the eastern La Valenciana depocentre. Given this geological configuration, it is a useful place to study the relationships between basement structures and cover deformation with respect to palaeogeography.

In the Cerro Doña Juana area (Figs 5, 6), the lower part of the Mesozoic succession (Puesto Araya Formation) lies on top of basement rocks of the Choyoi Group and the basement-cover interface dips at $45^{\circ}$ towards the SE. The Puesto Araya also thickens towards the $\mathrm{SE}$, and the dip values decrease towards the SE. The fact that dip values also decrease towards the top of the formation is evidence of a syndepositional wedgetype geometry, related to tectonic control of the Lower Jurassic sedimentation. This wedge-type geometry is therefore related to Lower Jurassic deformation. Given that the basement-cover interface is likely to be of sedimentary origin and the wedge shape of the Puesto Araya beds, we conclude that they are situated on a palaeo-basement high characterized by the onlap of Lower Jurassic beds during their deposition (Fig. 6). If considering the upper part of the wedge, the sedimentary beds exhibit low-amplitude folding associated with a NE-SW-trending fold axis. The cover has probably been gently strained during Andean shortening. In short, the Cerro Doña Juana area reveals an important degree of coupling between basement and cover associated with low Andean deformation. Given that the basement-cover interface is of sedimentary origin and dips at $45^{\circ} \mathrm{SE}$ at its maximum, it is unlikely that this geometry directly reflects the initial extensional geometry resulting from the rift stage (pre-contractional geometry; Fig. 6). Rather, this configuration indicates a gentle tilting of the whole structure during Andean shortening, which is also supported by the fact that the Choiyoi basement rocks lie on the surface to the west.
A few kilometres south of Las Leñas village (Fig. 7), a thin Mesozoic succession lies on top of the Choiyoi Group basement rocks. The sedimentary succession reaches a thickness of about $400 \mathrm{~m}$ from synrift rocks to the Tordillo red beds that form the highest relief in this area. On top of the basement rocks, the first deposits consist of channelized conglomerates and microconglomerates, reworking volcanoclastic elements and overlaid by an alternation of medium-grained to finegrained sandstones with abundant marine fossils and wood fragments. This succession characterizes the El Freno Formation. A series of fine-grained to mediumgrained sandstones belonging to the Puesto Araya Formation is then identified, followed by the Tres Esquinas quartz-rich black shales. The subsequent Tabanos and La Manga formations are represented by evaporites and carbonates rocks. The upper part of the succession consists of reds beds of volcanoclastic affinity that we attribute to the Tordillo Formation. No major decoupling surface between basement and cover is found (Fig. 7b), leading us to believe that cover and basement are mostly coupled in this area even if a thin gouge is observed between both units, attesting for some minor flexural slip. This sedimentary log corresponds to a condensed Mesozoic succession deposited on top the LLH, between the Rio Cobre and La Valenciana depocentres. The Andean shortening appears to be localized on this pre-existing basement high.

Figure 7a, c shows that, to the west, the LLH forms a kilometre-wavelength anticline, suggesting a deepseated deformation. Conversely, the Tordillo and Vaca Muerta formations to the east exhibit short-wavelength folding (of a few hundred metres) with frequently overturned geometries indicating shallow deformation. It is worth noting that similar deformational cover patterns were identified in the frontal Mallin Largo area (Fig. 8). 

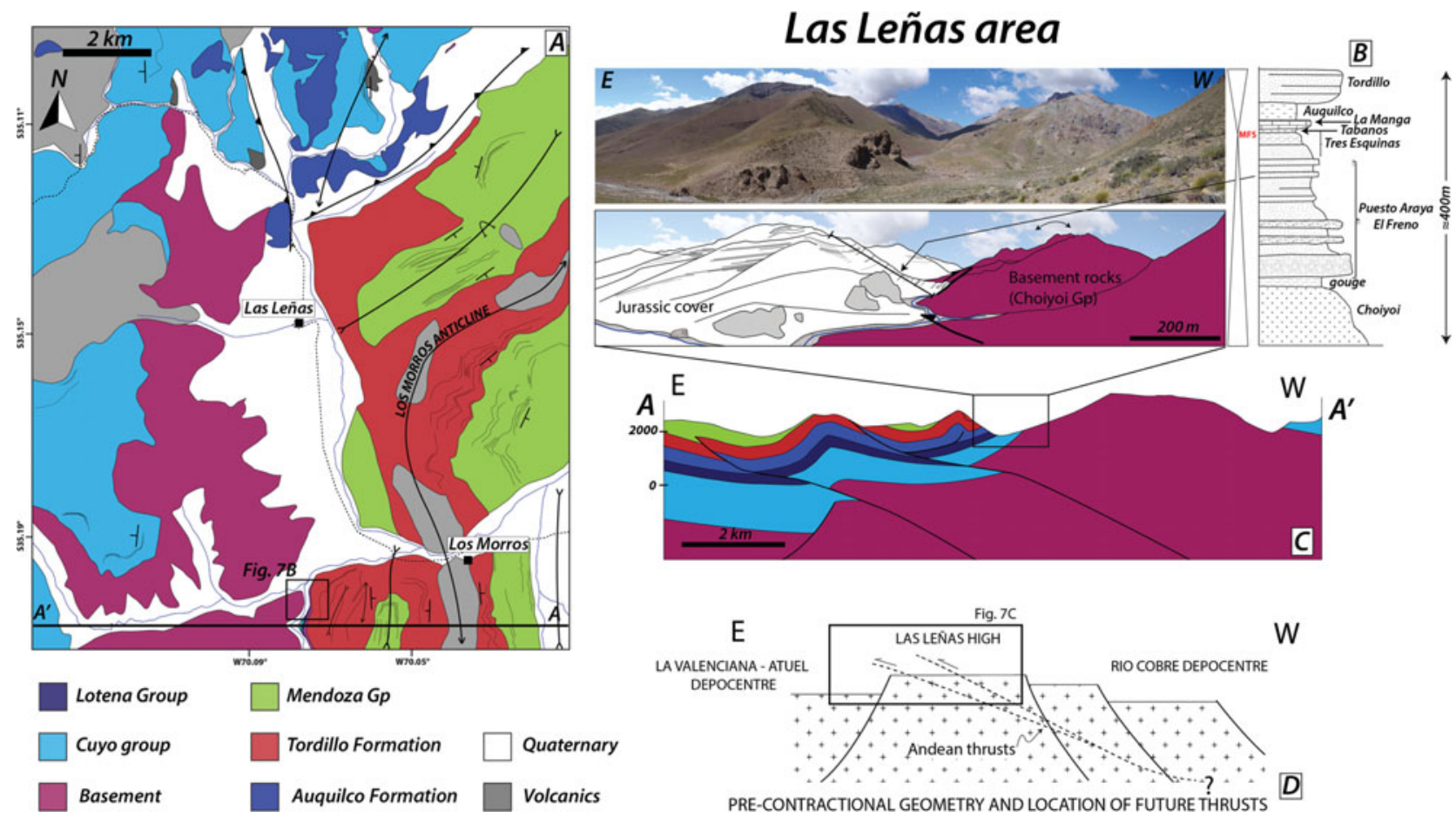

Figure 7. (a) Geological map of the Las Leñas domain based on Google Earth imagery. (b) Filed pictures and sedimentary log characterizing the reduced Mesozoic series on top of the Las Leñas High. (c) Depth interpretation showing the structure of both the Las Leñas High and the western part of the La Valenciana depocentre. (d) Pre-contractional geometry in the Las Leñas High area.
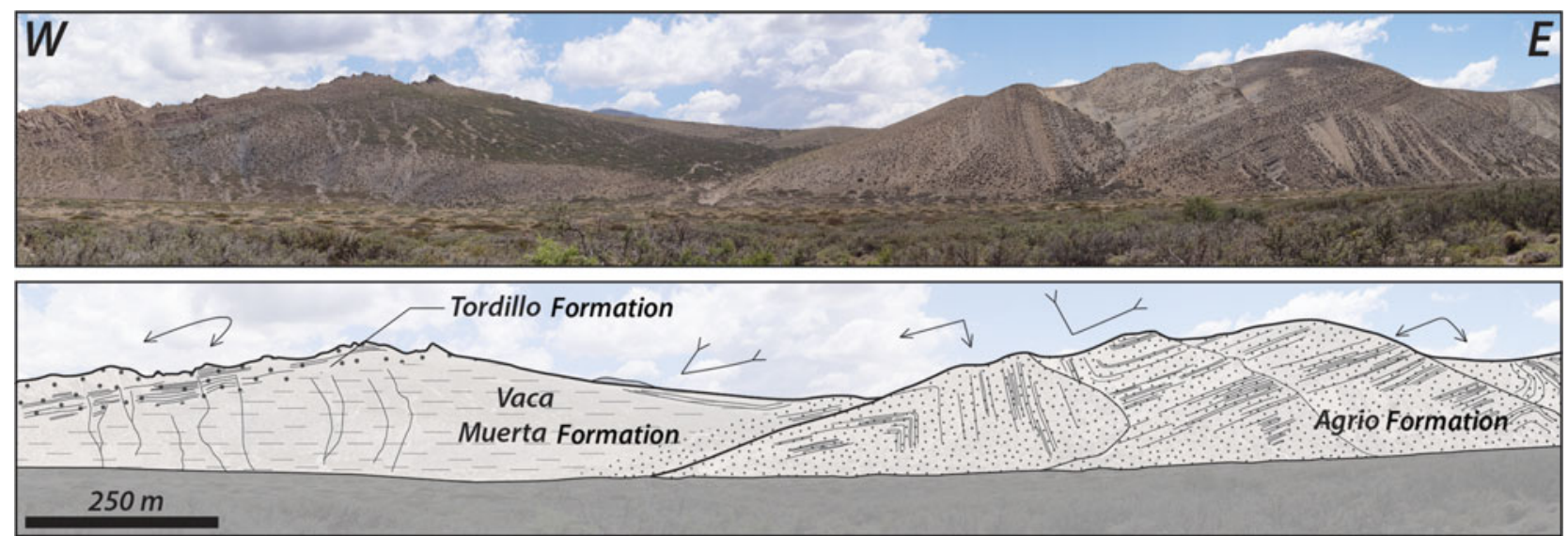

Figure 8. (Colour online) Succession of short-wavelength folds in the Mallin Largo area, the frontal part of the Rio Salado valley. These folds are interpreted to have developed as a result of the propagation of the basement deformation into the cover.

The fact that the Choiyoi Group rocks are found slightly topographically higher than the adjacent sedimentary cover reveals that the palaeo-high has been thrust. The small-wavelength folding we observe in this area suggests that two basement thrusts transferred part of their shortening to the overlying sedimentary column, which is passively uplifted and strained due to the existence of several efficient décollement levels (Fig. 7). It is clear that in the Las Leñas zone, tectonic transport is limited and cover is still attached to the underlying basement. Given the low tectonic transport, the strong coupling between basement and cover, and the known palaeogeography, two basements thrusts are needed to account for the folding pattern of the cover.
North of the Cerro Doña Juana area, the structural relationships between basement and cover are distinct (Figs 3, 9). From analysis of the satellite images, we found that the Upper Jurassic beds are directly above the Choiyoi basement rocks (Fig. 9). The Lower and Middle Jurassic beds are absent, suggesting that the basement-cover interface is tectonic. East of the basement-cover interface, sediments exhibit folding of wavelength $100 \mathrm{~m}$. The Tordillo and Vaca Muerta formations are almost vertical and folds are overturned towards the west. It is worth noting that given the eastwards direction of the basement thrusting, eastwards overturned fold are expected. According to our interpretation, the LLH uplift results from the propagation 


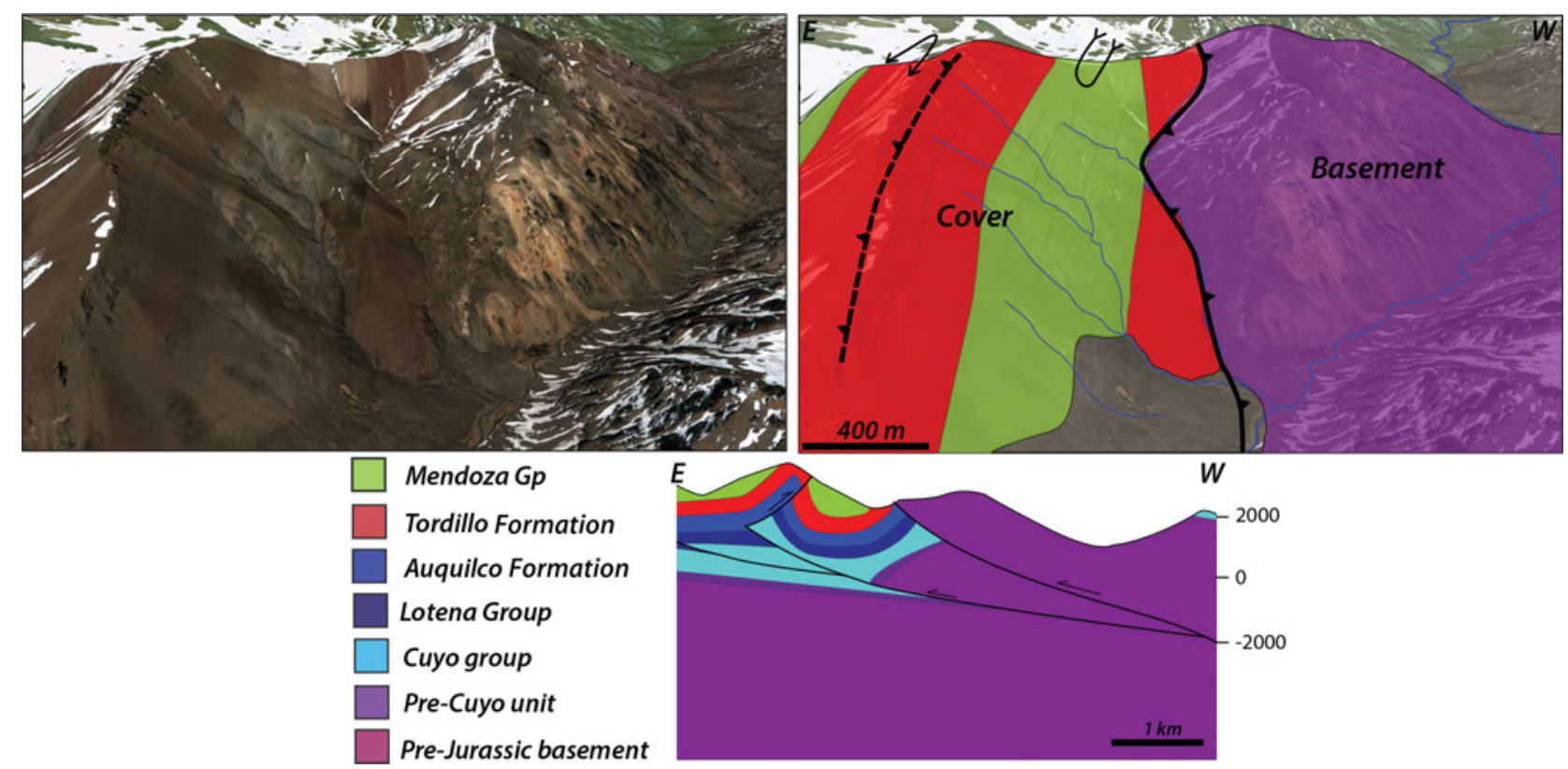

Figure 9. Google Earth image illustrating the thrusting of basement rocks over the Upper Jurassic sedimentary units along the Las Leñas High.

of two basement thrusts (Fig. 9). The fact the smallscale folds are overturned towards the west can be explained by the propagation of a secondary back-thrust connected to the lower basement fault, hence forming a fishtail-type or triangular system. This is the first place where basement and cover are found decoupled, allowing us to identify the emergence of a basement thrust.

The three examples given above show that at least a part of the Andean deformation localizes along this palaeo-high, providing contrasting sketches and geometries of basement-cover relationships.

\section{4.b. Malargüe Basin and anticline}

\section{4.b.1. Structural styles}

The Malargüe Basin (elsewhere known as the Pincheira-Ventana Basin) is limited to the west by the La Valenciana reliefs and bounded to the east by the Malargüe anticline, which corresponds to the Jurassic-aged and also the current eastern border of the exhumed Malargüe depocentre (Figs 3, 5, 10). Its structural location, where exhumation and erosion of the sedimentary infill are lower than in the innermost parts, allows the relationships between basement uplifts and synorogenic sedimentation to be investigated.

It is important to mention the presence of NNESSW-trending folds to the west, bringing to the surface the synrift Lower Jurassic units, and Middle-Late Jurassic strata to the east of the Malargüe depocentre, following the watercourse of the Malargüe River (Fig. 5) from La Valenciana towards Castillos de Pincheira city. The wavelength of the anticlines situated near the Valenciana locality reaches at least $2 \mathrm{~km}$, and their associated geographical extension of $c .20 \mathrm{~km}$ suggests basement-involved structures (Manceda \& Figueroa, 1995 ) with no emergence at the surface, rather than superficial structures confined to the sedimentary cover.

Eastwards we enter the Malargüe depocentre which is characterized by the large outcrops of Tertiary synorogenic series. Between Castillos de Pincheira and Malargüe we observe a tight N-S-trending syncline affecting the synorogenic beds, followed by the La Brea back-thrust which exhumes the upper Lower Cretaceous evaporites of the Rayoso Group (Figs 5, 10). The geographical extension of this back-thrust suggests a regional structure accommodating the Andean shortening. Eastwards, the Pincheira syncline corresponds to a kilometre-scale N-S-trending upright fold affecting the upper part of the Mesozoic cover (Fig. 10). The fold is symmetric (both limbs dip at $30^{\circ}$ ) and cored by the Malargüe Group carbonates. The eastwards limit of the Malargüe Basin is currently represented by the Malargüe basement-cored anticline (Fig. 11). It has a length of at least $30 \mathrm{~km}$ and a width of $c .8-10 \mathrm{~km}$ (Fig. 11). The folding affects the entire sedimentary pile from basement rocks to Lower Cretaceous deposits. Northwards, at the latitude of Rio Salado, seismic data indicate that the fold axis is buried below synorogenic deposits. Given the fold wavelength and the important lateral extension of the fold, it is clear that a substantial part of the shortening was accommodated by this frontal part of the belt.

Note that for cross-section drawing we use several industrial wells and seismic lines provided courtesy of Total Austral (Fig. 10). At depth, these constraints allow us to sketch a triangular zone known as the La Brea structure (Giambiagi et al. 2009a). We propose that the thrusts that generated the western NNW-trending folds near La Valenciana locality then propagated into the 


\section{Malargue depocentre}
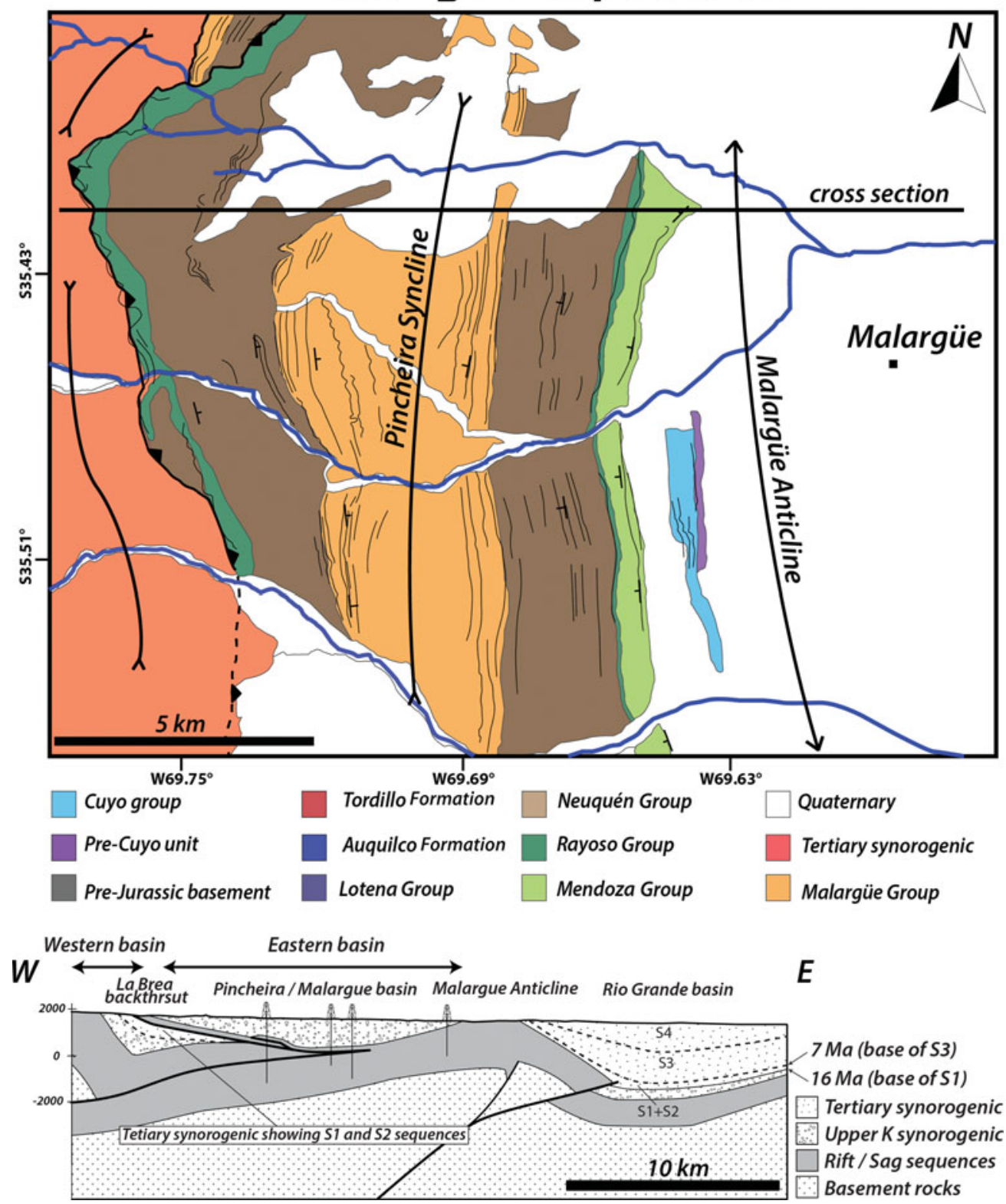

Figure 10. Geological map of the Pincheira syncline west of Malargüe city showing the outcrops of synorogenic units. The Neuquén Group rocks are found on both the limbs of the syncline, whereas Tertiary synorogenic strata are restricted west of the La Brea back-thrust. Below, structural cross-section focusing on the location and distribution of synorogenic sequences on both sides of the Malargüe anticline, based on Silvestro et al. (2009).

Malargüe depocentre, generating the duplexing of the Mendoza Group rocks at depth. Subsequently, the main thrust propagated upwards triggering the formation of a large passive roof structure, facilitated by the existence of the Rayoso evaporites (Fig. 10). This regional passive roof is currently represented by the La Brea backthrust (see Fig. 9). According to our interpretation, the Malargüe anticline results from the propagation of a western short-cut fault decapitating the head of the initial normal fault block (Fig. 11). Seismic and well data indicate that the forelimb of the fault is vertical, implying that basement rocks are also folded. Eastwards, another basement thrust is also proposed to account for the basement folding. We therefore propose that the Malargüe anticline is mainly uplifted by a newly formed basement thrust localized slightly east of the eastern edge of the initial extensional basin.

At the scale of the Malargüe depocentre, the major lines of the geological configuration are comparable to the Las Leñas area. Our interpretation suggests that the border of the La Valenciana depocentre was reactivated and two basements thrusts developed, promoting long wavelength folding. Indeed, two basement thrusts are necessary to produce both of the anticlines of the La Valenciana zone. Deep-seated shortening is then transferred to the neighbouring cover and triggers the formation of the La Brea triangular zone and the overlying Pincheira syncline. In terms of palaeogeography the 


\section{Malargue Anticline}
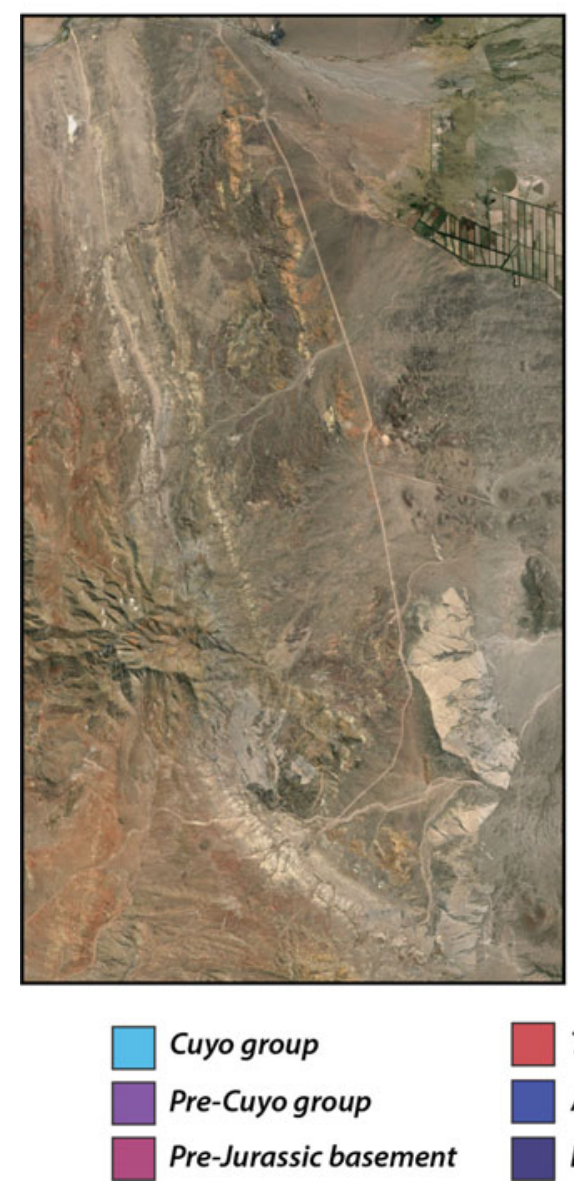
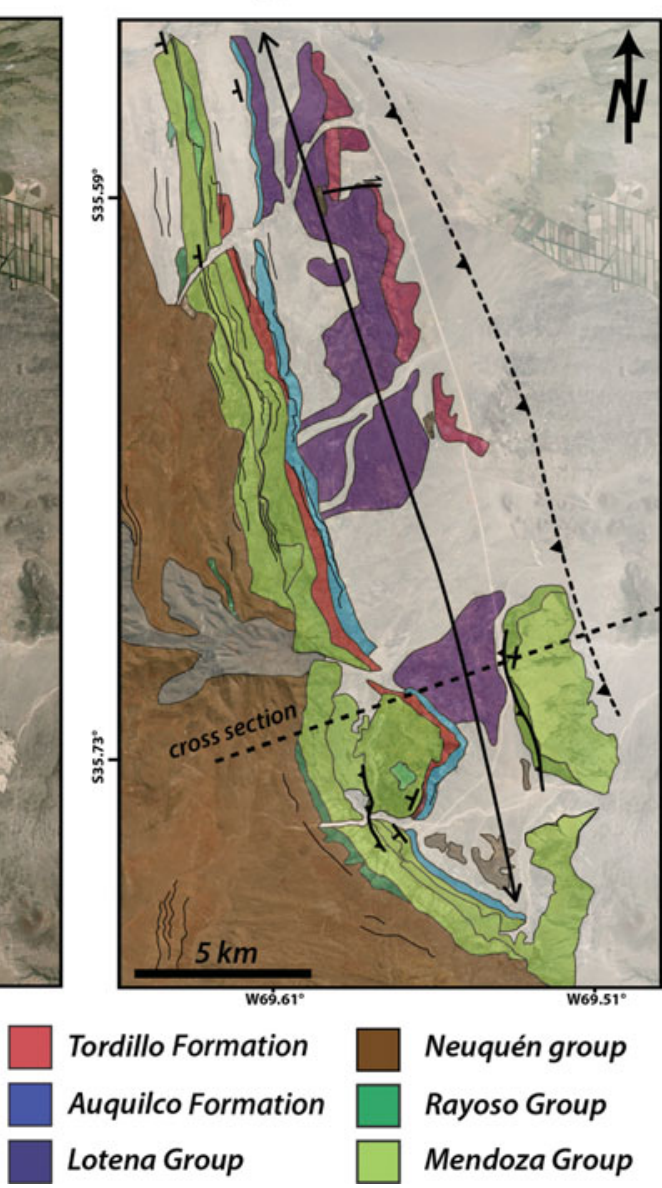

Initial extensive geometry
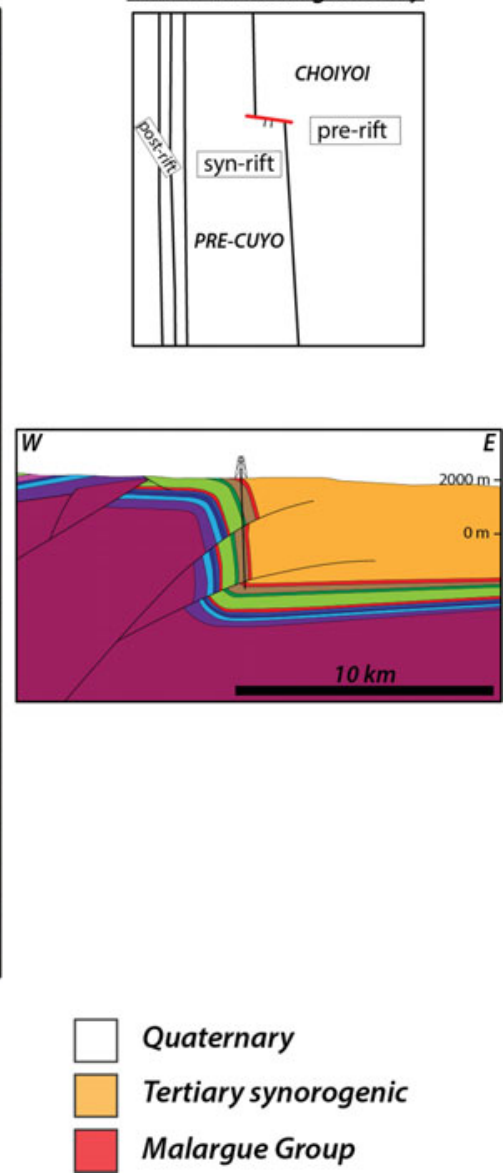

Figure 11. Google Earth image and the associated geological map of the frontal Malargüe anticline. The cross-section on the right illustrates the seismic and well-supported depth interpretation of the Malargüe anticline.

same applies for the Malargüe anticline, the former limit of the Malargüe depocentre (Figs 3, 11).

\section{4.b.2. Pattern of synorogenic sedimentation}

Above the La Brea triangular zone (Fig. 10), a thick Tertiary synorogenic series introduces constraints to the timing of sedimentation and deformation that we will discuss in Section 5.b (Silvestro et al. 2005; Combina \& Nullo, 2011; Kraemer et al. 2011). Starting from the Neuquén Group onwards, clastics sediments are considered as synorogenic (Fennell et al. 2015). In the Malargüe depocentre, the $1000 \mathrm{~m}$ thick Tertiary synorogenic sediments are restricted to the western basin (Fig. 10) as well as to the Rio Grande Basin where they reach a thickness of $c .2500 \mathrm{~m}$. During middle Miocene time, the Malargüe depocentre was limited to the west by the La Valenciana reliefs and to the east by the incipient Malargüe anticline. The La Brea back-thrust generated an internal relief that divided the Malargüe Basin into two sub-basins (Fig. 10).

Silvestro et al. (2005) show that the Tertiary synorogenic strata can be divided into four sequences. The first two sequences S1 and S2 are found on both sides of the Malargüe anticline, and their thickness can reach up to $800-1000 \mathrm{~m}$ and $600-800 \mathrm{~m}$, respectively, depending on the location. One striking feature of the whole middle Miocene sedimentation is that the thicknesses reach up to $1600 \mathrm{~m}$ in the Malargüe Basin but only $200 \mathrm{~m}$ in the Rio Grande depocentre. S1 mostly comprises volcanic rocks, sandstones and siltstones of the Agua de la Piedra Formation. The sequence S2 begins with fine-grained lacustrine deposits, attesting to a phase of tectonic and volcanic quiescence, but the Pincheira Formation conglomerates found on top of S2 mark the recovery of the tectonic activity. Then, during late Miocene time the sedimentary asymmetry switched, beginning during late Miocene time. Effectively, the sequences S3 and S4 reach a thickness of $350 \mathrm{~m}$ west of the Malargüe anticline, whereas they represent more than $1400 \mathrm{~m}$ of sediments east of the fold in the Rio Grande Basin. It is worth noting that $\mathrm{S} 4$ is restricted to the Rio Grande Basin. The sequences $\mathrm{S} 3$ and S4 consist of volcanic and clastic rocks, respectively.

\section{4.c. The San Rafael area}

Based on the two examples given in Sections 4.a and 4.b we established that the successive pulses of shortening, which occurred during Late Cretaceous - late 
Miocene time, triggered the reactivation of the borders of the early half-grabens, producing various contractional geometries involving basement rocks and generating atypical patterns of sedimentation in short-lived intramontane synorogenic basins (i.e. Pincheira Basin). The structural analysis of the SRB area has mainly been undertaken: (1) because shortening has already been documented in this area (Branellec et al. 2015a); and (2) since it can potentially help us to better understand the deformational mechanisms governing the active strain domain.

All the results of the geomorphological study performed along the eastern border of the SRB area are detailed in the companion paper (Branellec et al. 2016). We studied the two most important faults in this area, the Las Malvinas and Cerro Negro faults (Fig. 12). A $20 \mathrm{~m}$ high topographic ridge is observed along the northern Cerro Negro Fault, the growth of which caused the reorganization of the drainage system in this area. Similarly, in the aplomb of the southern Las Malvinas Fault, the Quaternary lavas are folded and an alluvial terrace is uplifted (Fig. 12). This geomorphic evidence indicates that recent Andean shortening has been partly accommodated along the eastern border of the SRB (Costa et al. 2006).

\section{Discussion: mode of FTB building}

\section{5.a. Structural response to shortening}

The basement high of Las Leñas is located in the core of the MFTB where exhumation is greatest and the structural maturity is expected to be the strongest. The Mesozoic sedimentary series on top of the Choiyoi Formation (Fig. 7) provides evidence of a marine transition from basinal to lagoon depositional environments. The transition is $400 \mathrm{~m}$ thick above the Las Leñas High, whereas the sedimentary thicknesses reported to the west and to the east can reach several thousand metres (Manceda \& Figueroa, 1995; Mescua et al. 2014). The Las Leñas sedimentary log corresponds to a reduced Mesozoic sequence showing basin shallowing, which is a typical pattern of sedimentation occurring above structural highs. This observation implies that the deformation localized along the border of a basement high.

Other evidence of basement uplift was retrieved in the southernmost part of the LLH in the Cerro Doña Juana area (Fig. 6) as well as few kilometres northwards (Fig. 9). These examples represent three distinct stages of tectonic maturity of the inversion process. In the Cerro Doña Juana area, the sedimentary cover is poorly deformed and shows a wedge-type geometry we interpret as a remnant of the early Mesozoic extensional stage of deformation. This means that the cover has just been uplifted and slightly strained above a blind basement fault. This stage characterizes the 'early' stage of inversion, where the cover mimics the pattern of deep-seated deformation.
East of the Las Leñas basement high, in the western part of the La Valenciana depocentre, the Mesozoic rocks are intensively strained (Fig. 7) and folds are frequently overturned with typical wavelengths of $<1 \mathrm{~km}$. This pattern is likely to result from basement thrust propagation into the adjacent thin sedimentary cover, triggering thin-skinned deformation. This deformation is characterized by an alternation of several synclines and anticline in front of the LLH which activates the décollement levels lying in the Mesozoic cover. This example shows an 'intermediate' state of deformation.

The most mature configuration is found south of Las Leñas and north of Cerro Doña Juana (Fig. 9). Crustal deformation emerges in this area, leading to the juxtaposition of basement rocks above the sedimentary cover. The way in which sediments accommodate shortening is different because of the emergence of the basement thrust. The three presented cases of basement and cover deformation along the pre-existing LLH could be attributed to case $\mathrm{C}$ depicted in Figure 2 because (1) no normal fault inversions were identified on the field; and (2) thrusting does not occur in the core of depocentre, but rather appears localized along the preexisting LLH. This interpretation is supported by the regional cross-section provided by Mescua et al. (2014) where the LLH contractional pattern is related to the possible inversion at depth of one the Rio Cobre listric normal faults evolving through a short-cut fault upwards.

It is interesting to note that these schemes also apply in the frontal part of the MFTB but also in the distal foreland along the border of the San Rafael Block. This important exhumation, which enabled us to analyse the mechanism that led to the reactivation of the Jurassic basins in the Las Leñas area, becomes an issue for the study of the sedimentological response to Andean deformation because of the erosion of synorogenic units. Conversely, in the frontal part of the belt west of Malargüe city, thick synorogenic successions are well preserved, allowing the relationships between syntectonic sedimentation and basement uplift to be investigated.

\section{5.b. Sedimentary response to shortening}

The Malargüe area has been targeted by the oil industry because of the existence of the La Brea triangular zone (Figs 10,11) which has been operational for several decades, giving access to seismic and well data. Similarly to the Las Leñas region, the Malargüe area corresponds to the eastern border of the Early Jurassic basin that has been thrust at depth (Figs 6,11), triggering the deformation of the adjacent cover. This area is interesting due to its more distal position, which allowed the preservation of the syntectonic sedimentary units (Fig. 10; Combina \& Nullo, 2011; Silvestro et al. 2005).

The thickness of S1-S2 is eight times higher in the southern Malargüe Basin between the Valenciana thrust 


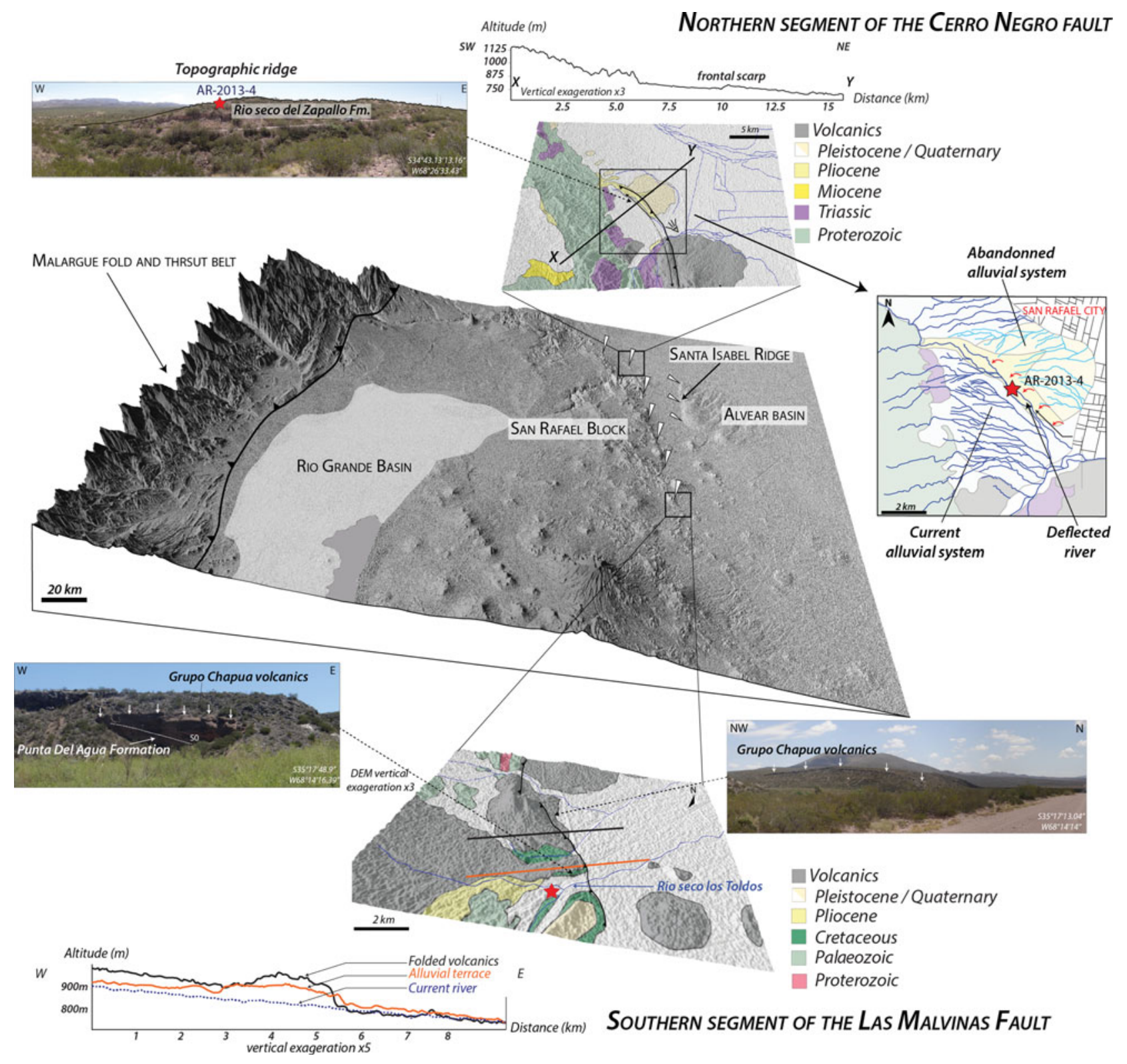

Figure 12. ASTER GDEM of the study area showing the Quaternary uplift of the eastern border of the San Rafael Block. The activity of the northern Cerro Negro Fault is associated with the formation of a topographic ridge and triggered the reorganization of the drainage system. The tectonic activity of the southern Las Malvinas Fault has been identified as a result of the deformation of Quaternary lavas and terraces.

and the Malargüe anticline than in the Rio Grande depocentre (Fig. 10). This suggests that the activity of these basement structures in generating a high topography, controlled the restriction of the synorogenic sedimentation to the Malargüe Basin. To the north the sedimentation has been controlled by the La Brea thrust to the west; meanwhile eastwards, the Malargüe anticline was already developed. Subsequently, the sedimentation jumped forwards in the Rio Grande Basin where the S3-S4 interval is ten times thicker than S3 in the Malargüe Basin. The absence of S4 in the latter basin is evidence of the cessation of the synorogenic deposition at that time. The volcanic contents in S1 and S3 have been dated to 16 and 7 Ma respectively, based on radiometric dating (Silvestro et al. 2005). This ob- servation implies that the Malargüe anticline was active during this period, whereas the Valenciana thrust was no longer active after $7 \mathrm{Ma}$.

The sedimentation pattern of the Malargüe Basin therefore presents all the characteristics of an intramontane basin. The variable thicknesses of S1 and S2 between the Malargüe and Rio Grande basins imply that the sediment supply was mainly stored in the Malargüe depocentre. Clast content and sedimentological analyses showed that the La Valenciana area and the Malargüe anticline remained the feeding relief for erosion products until S3 was deposited (Silvestro et al. 2005). The lacustrine deposits at the bottom of S2 suggest that the Malargüe Basin was potentially disconnected from its foreland area; it probably reached 
endoreic conditions in response to an inadequate hydrological drainage system with respect to the uplift rate of the tectonic barrier, or maybe because the rivers were not able to transport the whole sedimentary supply. In this way, sediments were stored in the intramontane depocentre to the detriment of an under-filled foreland basin (e.g. Mortimer et al. 2007). The overfilling of the Malargüe Basin is therefore not necessarily linked to subsidence but rather to a deficiency of surface processes. Another important common feature of intramontane basins is that, once the depocentre began exhumation its drainage system was able to reconnect to that of the foreland (Huyghe et al. 2015). This reconnection is supported by the non-deposition of sequence S4 west of the Malargüe anticline and by the erosion of sequences $\mathrm{S} 1$ and S2 in the northern part of the Malargüe depocentre between the La Brea back-thrust and the Malargüe anticline.

The restriction of sedimentation in a short-lived intramontane basin is characteristic of a broken foreland system (Hain et al. 2011; Strecker et al. 2011). The wide distribution and the geometry of the Neuquén Group rocks that progressively thin away from the orogenic front in the southern Neuquén Basin (e.g. Cobbold \& Rossello, 2003) are indicative of an Upper Cretaceous palaeo-foreland (Fennell et al. 2015). The latter has subsequently been broken by the development of the Las Leñas uplift and later eroded in the most exhumed domain.

Such geometries are found elsewhere along the Andean front (e.g. Hilley, Blisniuk \& Strecker, 2005; Mortimer et al. 2007; Carrapa et al. 2008; Carrapa, Trimble \& Stockli, 2011; Morabito, Götze \& Ramos, 2011; Siks \& Horton, 2011; Strecker et al. 2011; Huyghe et al. 2015). For instance, in the southern part of the Neuquén Basin the Collon Cura intramontane basin shows thicknesses of $c .300 \mathrm{~m}$, whereas its associated foreland exposes smaller values of $c .180 \mathrm{~m}$ (Huyghe et al. 2015). If considering the localization of subsidence and the preservation of synorogenic deposits, in the Quebrada del Toro Basin in NW Argentina (Hilley \& Strecker, 2005) the geomorphic and geological observations indicate that the basin was filled with sediment that has previously been excavated at least twice in the last $c$. 8 Ma. Nevertheless, the model we put forward in the MFTB differs from what have been described in northern Argentina.

Following the initial stages of syntectonic filling of the Malargüe Basin (S1-S3) and the shift of the sedimentary accumulation to the Rio Grande Basin (S3, S4), the S1 and S2 sequences lying between the la Brea back-thrust and the Malargüe anticline began to be eroded (Fig. 10). West of the la Brea back-thrust, S1 and $\mathrm{S} 2$ are still preserved but will probably be submitted to erosion in a geologically near future. However, the subsidence of the basin was sufficiently high because the lower part of the tertiary infill is currently situated significantly lower than the present-day base level controlled by the subsidence of the Rio Grande
Basin. The scheme also applies for the Collon Cura Basin, which was still subsiding during Pliocene times despite its reconnection with the foreland. Indeed, in such a situation basin exhumation and erosion would be expected, which is why we can propose that the Malargüe Basin is likely to be preserved in the future.

The vergence of the main tectonic barrier is one of the main controlling factors, among others, affecting the dynamic of subsidence or uplift of intramontane depocentres. The vergence towards the hinterland of the Sañico massif in southern Neuquén province, which was individualized from the foreland basin and induced the development of the Collon Cura Basin, exerts a local tectonic loading, accentuating the magnitude of the subsidence (Huyghe et al. 2015). When the vergence of the main tectonic barrier is towards the foreland, the classical flexural foreland dynamic is recovered. This is what we currently observed in the Rio Grande Basin which is characterized by the steady thinning of the sedimentary fill towards the San Rafael Block.

An important point to consider concerning the interactions between the reactivation process and the sedimentary dynamic of adjacent basins concerns the depth to the décollement level. Effectively, a shallow deformation is likely to generate lower tectonic barriers, compared to deep-seated thrusting. For surficial deformation, the associated reliefs are topographically lower and narrower due to their reduced wavelength, and are therefore less able to deeply influence the organization of the drainage system in time and space. Frequently associated with deep-seated deformation, the shallow deformation also creates smaller, local rather than regional, accommodation area for the aggrading sedimentary units.

\section{5.c. Morphologic response to shortening}

The San Rafael Block is a horst surrounded by the Rio Grande Basin to the west and the Alvear Basin to the east. An important Quaternary tectonic activity has been documented along its eastern border (Figs 5, 12; Branellec et al. 2016). Due to a destructive earthquake that occurred on 30 May 1929, the area has been intensively investigated. Potential fault sources have been explored along both sides of the horst. The most convincing clues of recent tectonic activity are retrieved along two faults (Figs 3, 12): to the north the $30 \mathrm{~km}$ long and NNW-SSE-trending Cerro Negro Fault; and to the south the $45 \mathrm{~km}$ long and N-S-trending Las Malvinas Fault. We describe the morphological markers that indicate on-going tectonic activity along these faults in the companion paper (Branellec et al. 2016) and assume, as for Costa et al. (2006), that these two faults can potentially be responsible for earthquakes with magnitudes higher than $M_{\mathrm{w}}=6$. The Pleistocene slip rates range from $2.23 \pm 0.6$ to $1.77 \pm 0.54 \mathrm{~mm} \mathrm{a}^{-1}$ for the southern Las Malvinas Fault segment, and from $2.50 \pm 0.78$ to $1.96 \pm 0.68 \mathrm{~mm} \mathrm{a}^{-1}$ for the northern Cerro Negro Fault segment. 


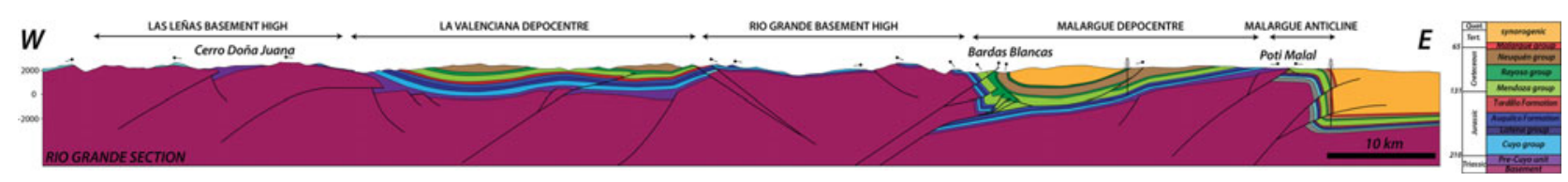

Figure 13. Well- and seismic-supported Rio Grande section running from the southern termination of the Las Leñas High to the Rio Grande Basin.

Located $11 \mathrm{~km}$ east of the Cerro Negro Fault, the Santa Isabel ridge rises in the lowland and reaches an altitude of about $750 \mathrm{~m}$. It shows a N-S-trending, 100-150 $\mathrm{m}$ high and $20 \mathrm{~km}$ long escarpment (Figs 5, 12). This topographic ridge that is located in a flat environment could have resulted from the activation of the border of the SRB. This activation could have triggered shallow thin-skinned deformation on the adjacent synorogenic deposits. Indeed, as no thrust emergence can be detected in the field, it is likely that the basement thrust transmitted the shortening to the adjacent sediment fill within the Alvear Basin. The Las Leñas area exhibits a similar geometry as well as relationship between deep-seated and shallow deformation (Section 4.1; Fig. 7).

Baker et al. (2009) have estimated the incision rate of the Diamante River that runs through the northern termination of the SRB. The long-term average rate of bedrock incision reaches $0.1-0.5 \mathrm{~mm} \mathrm{a}^{-1}$, and the short-term rates equates to $2 \mathrm{~mm} \mathrm{a}^{-1}$. These incision rates are in good agreement with the estimated slip rates on the Las Malvinas and Cerro Negro faults, suggesting that the Quaternary uplift of the piedmont area is probably the cause of the incision. The good match between incision and deformation rates invalidates the hypothesis of Baker et al. (2009), according to which the present-day incision could be alternatively attributed to a delayed response of pre- to middle Quaternary uplift. These authors have also pointed out a possible response to climate change and sediment supply on a tectonically stable portion of the piedmont.

We conclude that during late Quaternary times strain velocities were not sufficiently high to disconnect the Rio Grande Basin from its foreland: rivers such as the Diamante River were still able to balance the tectonic uplift of the SRB. The continuity of the sedimentary connection between the hinterland and the foreland also applies for the Atuel River, which is a significantly lower watercourse. Above the Malvinas Fault, the continuity of the drainage system on both sides of the fault shows the same configuration with short-lived rivulets (see Branellec et al. 2016). For the Cerro Negro Fault, the rivers have been diverted above the fault but the continuity of the drainage system between the Rio Grande and Alvear basins is still preserved. Climatic forcing should also be integrated in the comprehension of the interaction between fragmentation of the foreland and the growth of intramontane basins (Strecker et al. 2007, 2009).

\section{5.d. Structural analogies between finite strain and active deformation patterns}

Similarly to the Las Leñas High, it is the eastern border of the SRB that seems to accommodate the current shortening along the SRB. The fact that the Miocene deposits of the Aisol Formation currently onlap the SRB (Fig. 5) suggests that the recent deformation did not strongly affect them. These deposits lay $1000 \mathrm{~m}$ higher than the Quaternary infill of the Alvear foreland basin. This structural style is therefore comparable to the situation observed in the Bardas Blancas area, which is characterized by a localization of the deformation along the eastern border of the inherited Rio Grande High (RGH). In summary, the western border of the RGH as well as the SRB appears poorly deformed (see Section 6).

The structural scenario highlighted in the Las Leñas area is likely to have occurred by Late Cretaceous times during the Peruvian stage in the core of the fold-andthrust belt, and to have been repeated in the frontal part of the belt probably during the Quechua stage by Miocene times. This scenario is today observed along the eastern border of the San Rafael Block associated with a jump in the deformation as far as $100 \mathrm{~km}$ away from the MFTB front. It has to be noted that this deformation jump did not affect the sediments lying in the Rio Grande Basin.

From Late Cretaceous time to the present day, the repetition of a common structural scheme in the various places of the fold-and-thrust belt highlights: (1) the key role of the pre-existing extensional structures on the localization of Andean shortening; and (2) the temporal continuity of FTB-building mechanisms.

\section{A forward scenario for MFTB building}

\section{6.a. Rio Grande section}

The southern Rio Grande section (Fig. 13) is a good example for illustrating all the structural and sedimentological mechanisms responsible for the building of the MFTB (Branellec et al. 2015b, 2016). This crosssection was built using two wells and one seismic line that was available in the Malargüe anticline area.

On the westernmost part of the southernmost Rio Grande section, we can see the southern termination of the LLH characterized by synrift rock outcrops overlying the basement rocks (Fig. 6). Advancing eastwards, we enter the La Valenciana depocentre which exhibits large-wavelength folding likely to be controlled by 


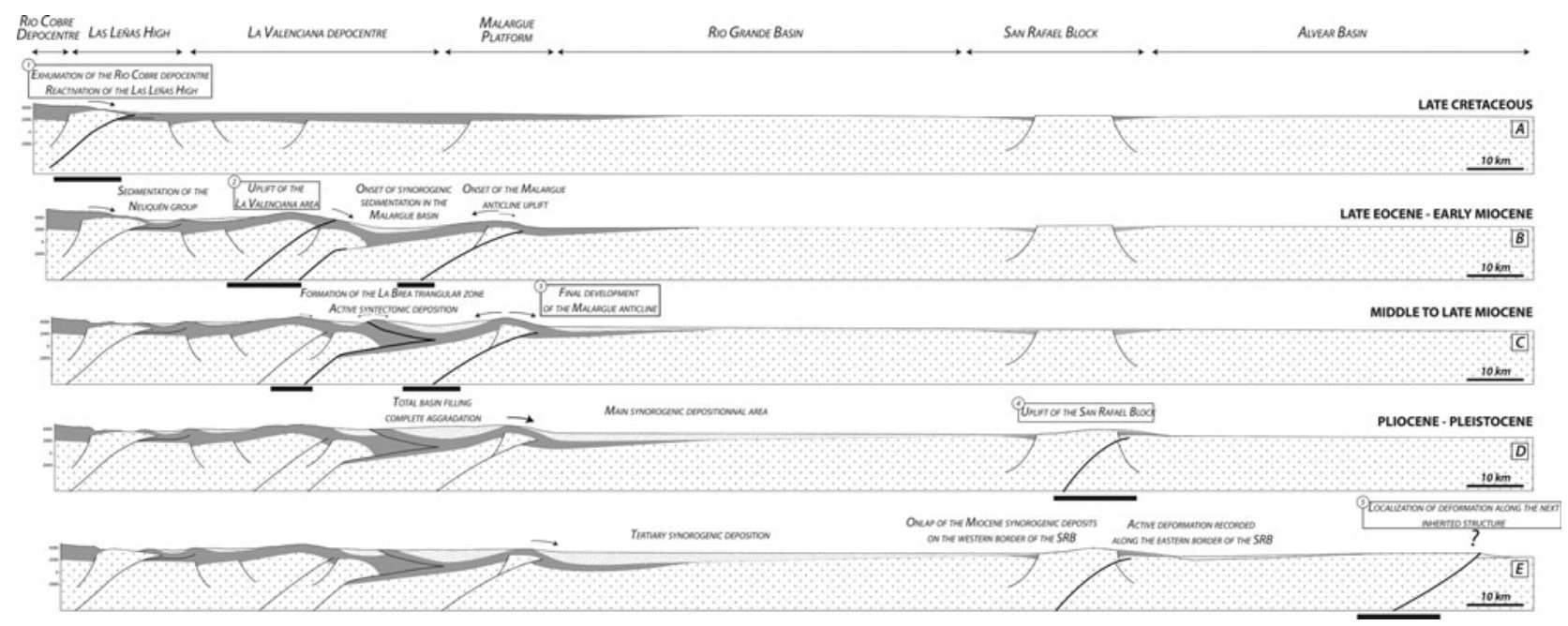

Figure 14. Kinematic evolution of the MFTB and SRB, emphasizing the structural, sedimentary and morphologic response to Andean shortening. Deformation basically propagates from west to east and jumps from one inherited structure to another, triggering synorogenic sedimentation in adjacent depocentres. We established that during Late Cretaceous - Quaternary times the same structural scheme applies in the Las Leñas area, the Malargüe depocentre and, today, along the eastern border of the San Rafael Block.

deep-seated basement thrusting. The youngest rocks involved in the folding process are the red beds of the synorogenic Neuquén Formation. Considering the La Valenciana Basin as a palaeo-accommodation zone, clastics accumulating from the erosion of the inner part of the belt began to build up in a short-lived intramontane basin. It is probable that, at the time of the Rio Grande High (RGH) uplift, the La Valenciana depocentre was closed and trapped within the fold belt.

Continuing eastwards, the RGH consists of a large province of basement rocks overlaid by thin Middle Jurassic deposits. It is worth noting that the western border of the RGH is not as deformed as the eastern border, which has been uplifted by major basements thrusts in the vicinity of Bardas Blancas (Dicarlo \& Cristallini, 2007). Indeed, the activation of the oriental border triggered thin-skinned deformation in the adjacent Malargüe depocentre, since the basement deformation was transmitted to the cover via the Vaca Muerta shales decoupling level. In the western part of the Malargüe depocentre, the cover is intensively strained at depth and characterized by duplex development within the Mendoza Group rocks.

A few kilometres eastwards, within the Malargüe depocentre itself, we observe a syncline structure with a slightly overturned western limb, explaining the westdipping strata of the Neuquén Group on the surface. A thick sedimentary accumulation of Tertiary synorogenic deposits is found on top of the Neuquén and Malargüe Group rocks, attesting for a palaeoaccommodation zone that accumulated large amounts of synorogenic deposits. It has to be noted that, apart from the antiformal stack and associated duplexing structures, the Malargüe depocentre was not subject to a high degree of deformation, as evidenced by the long west-dipping monocline from Bardas Blancas to Poti Malal. This monocline also forms the back-limb of the frontal Malargüe anticline, which is flanked to the east by the Rio Grande intramontane basin.

\section{6.b. A kinematic model of deformation propagation across the MFTB}

Figure 14 depicts a possible kinematic scenario of deformation propagation based on all the information provided in this article. The overall geological history at the latitude of the Malargüe Basin can be divided into five main stages as follows.

(1) Probably by Late Cretaceous times, the Rio Cobre depocentre was exhumed and the eastern border of the LLH was uplifted, leading to synorogenic deposition in the La Valenciana foreland basin. The numerous remnants of the Neuquén Group rocks found in the La Valenciana depocentre provide evidence of this synorogenic deposition stage (Fig. 14a).

(2) During early Miocene times (Silvestro et al. 2005), the deformation jumped to the La Valenciana area coevally with the onset of the Malargüe anticline development. Consequently, synorogenic deposition was restricted to the Malargüe Basin and sequence $\mathrm{S} 1 \mathrm{was}$ deposited at that time. The western part of the La Valenciana depocentre was then passively transported (Fig. 14b).

(3) The third stage is characterized by the final development of the La Brea triangular zone that generated an internal high and by the final growth of the Malargüe anticline by middle Miocene times. Sequences S1 and S2 were deposited on both sides of the Malargüe anticline but remained eight times thicker in the Malargüe depocentre than in the Rio Grande area (Fig. 14c).

(4) Beginning during late Miocene time, the sedimentation switched in the Rio Grande area that became the main depositional area. This is supported by the fact that sequences S3 and S4 are ten times thicker in the Rio Grande Basin than in the Malargüe depocentre. 
The Malargüe Basin was uplifted and submitted to exhumation, as indicated by erosion of sequences $\mathrm{S} 1$ and S2. Eastwards, the eastern border of the SRB began to localize active deformation (Fig. 14d).

(5) The final stage represents the present day and potentially the future configuration in the distal foreland area. Active deformation is recorded along the eastern border of the SRB, whereas its western border is not active as evidenced by its onlap of the Miocene synorogenic sediments. At this stage we also address the question of the localization of the future deformation, and propose that it is likely to localize along the next inherited structure towards the east (Fig. 14e).

Acknowledgements. The authors warmly thank the Total group for financial support and field logistics. We are also grateful to the Total Austral subsidiary (Total Austral) for providing us with the seismic and well data and to JeanFrançois Ballard for fruitful discussions in the field. Authors also thank Marco Bonini and one anonymous reviewer for their comments and suggestions which greatly improved the paper.

\section{References}

BaKer, S. E., Gosse, J. C., McDonald, E. V., Evenson, E. B. \& MARTínEZ, O. 2009. Quaternary history of the piedmont reach of Río Diamante, Argentina. Journal of South American Earth Sciences 28(1), 54-73.

Bonini, M., SANI, F. \& ANTONIElli, B. 2012. Basin inversion and contractional reactivation of inherited normal faults: a review based on previous and new experimental models. Tectonophysics 522-523, 55-88.

Branellec, M., Callot, J. P., Aubourg, C., Nivière, B. \& RINGENBACH, J. C. 2015a. Matrix deformation in a basement-involved fold-and-thrust-belt: a case study in the central Andes, Malargue (Argentina). Tectonophysics 658, 186-205.

Branellec, M., Callot, J. P., Nivière, B. \& Ringenbach, J. C. $2015 b$. The fracture network, a proxy for mesoscale deformation: constraints on layer parallel shortening history from the Malargue fold and thrust belt, Argentina. Tectonics 34(4), 2014TC003738.

Branellec, M., NiviÈre, B., Callot, J.-P., Regard, V. \& RINGENBACH, J.-C. 2016. Evidence of active shortening along the eastern border of the San Rafael basement block: characterization of the seismic source of the Villa Atuel earthquake (1929), Mendoza province, Argentina. Geological Magazine vol (this issue), $\mathrm{xx}-\mathrm{xx}$.

BRUN, J.-P. \& NALPAS, T. 1996. Graben inversion in nature and experiments. Tectonics 15(3), 677-87.

Carrapa, B., Hauer, J., Schoenbohm, L., Strecker, M. R., Schmitt, A. K., Villanueva, A. \& Gomez, J. S. 2008. Dynamics of deformation and sedimentation in the northern Sierras Pampeanas: an integrated study of the Neogene Fiambalá basin, NW Argentina. Geological Society of America Bulletin 120(11-12), 1518-43.

Carrapa, B., Trimble, J. D. \& Stockli, D. F. 2011. Patterns and timing of exhumation and deformation in the Eastern Cordillera of NW Argentina revealed by (U-Th)/He thermochronology. Tectonics 30(3), doi: 10.1029/2010TC002707.

Cingolani, C., Llambías, E., Basei, M., Varela, R., Chemale JR, F. \& ABRe, P. 2005. Grenvillian and Famatinian-age igneous events in the San Rafael Block,
Mendoza Province, Argentina: geochemical and isotopic constraints. Gondwana 12, 250.

Cobbold, P. R. \& Rossello, E. A. 2003. Aptian to recent compressional deformation, foothills of the Neuquén Basin, Argentina. Marine and Petroleum Geology 20(5), 429-43.

Combina, A. M. \& Nullo, F. 2011. Ciclos tectónicos, volcánicos y sedimentarios del Cenozoico del sur de Mendoza-Argentina $\left(35^{\circ}-37^{\circ} \mathrm{S}\right.$ y $\left.69^{\circ} 30^{\prime} \mathrm{W}\right)$. Andean Geology 38(1), 198-218.

Costa, C., Cisneros, H., Salvarredi, J. \& Gallucci, A. 2006. La neotectónica del margen oriental del bloque de San Rafael: nuevas consideraciones. Asociación Geológica Argentina, Serie D: Publicación Especial 6, 33-40.

DiCARLO, D. J. \& CRISTALlini, E. 2007. Estructura de la margen norte del Río Grande, Bardas Blancas, provincia de Mendoza. Revista de la Asociación Geológica Argentina 62, 187-99.

Dimieri, L. \& Nullo, F. 1993. Estructura del frente montañoso de la Cordillera Principal ( $36^{\circ}$ latitud sur), Mendoza. In 12 Congreso Geológico Argentino y 2 Congreso Nacional de Exploración de Hidrocarburos. Mendoza, Actas 3, pp. 160-7.

Dimieri, L. V. \& TURIEnZO, M. M. 2012. Comment on: "Fault inversion vs. new thrust generation: a case study in the Malargue fold-and-thrust belt, Andes of Argentina" by JF Mescua, and LB Giambiagi, Journal of Structural Geology 35 (2012) 51-63. Journal of Structural Geo$\log y$ 42, 279-82.

Fennell, L. M., Folguera, A., Naipauer, M., Gianni, G., Rojas Vera, E. A., Bottesi, G. \& Ramos, V. A. 2015. Cretaceous deformation of the southern Central Andes: synorogenic growth strata in the Neuquén Group $\left(35^{\circ} 30^{\prime}-37^{\circ} \mathrm{S}\right)$. Basin Research, published online 3 June 2015, doi: 10.1111/bre.12135.

FolguerA, A., BOTTESI, G., DUDDY, I., MARTíN-GONZÁLEZ, F., Orts, D., SAgripanti, L., Vera, E. R. \& Ramos, V. 2015. Exhumation of the Neuquén Basin in the southern Central Andes (Malargue fold and thrust belt) from field data and low-temperature thermochronology. Journal of South American Earth Sciences 64(2), 381-98.

FranZeSE, J. R. \& SPALlETti, L. A. 2001. Late Triassic-early Jurassic continental extension in southwestern Gondwana: tectonic segmentation and pre-break-up rifting. Journal of South American Earth Sciences 14(3), 25770.

Giambiagi, L., BeChis, F., GARCíA, V. \& ClaRK, A. H. 2008. Temporal and spatial relationships of thick- and thinskinned deformation: a case study from the Malargue fold-and-thrust belt, southern Central Andes. Tectonophysics 459(1-4), 123-39.

Giambiagi, L., Ghiglione, M., CRistallini, E. \& BotTesi, G. 2009a. Kinematic models of basement/cover interaction: insights from the Malargue fold and thrust belt, Mendoza, Argentina. Journal of Structural Geology 31(12), 1443-57.

Giambiagi, L., TuniK, M., Barredo, S., Bechis, F., Ghiglione, M., Alvarez, P. \& Drosina, M. $2009 b$. Cinemática de apertura del sector norte de la Cuenca Neuquina. Revista de la Asociación Geológica Argentina 65, 278-92.

Hain, M. P., Strecker, M. R., Bookhagen, B., Alonso, R. N., Pingel, H. \& SchmitT, A. K. 2011. Neogene to Quaternary broken foreland formation and sedimentation dynamics in the Andes of NW Argentina (25 S). Tectonics 30(2), doi: 10.1029/2010TC002703.

HALler, M. \& RAMOS, V. A. 1984. Las ofiolitas famatinianas (Eopaleozoico) de las provincias de San Juan y 
Mendoza. In Actas, IX Congreso Geológico Argentino. San Carlos de Bariloche, Argentina, Asociación Geológica Argentina, pp. 66-83.

Hilley, G., Blisniuk, P. \& Strecker, M. 2005. Mechanics and erosion of basement-cored uplift provinces. Journal of Geophysical Research: Solid Earth (19782012) 110(B12), doi: 10.1029/2005JB003704.

HiLley, G. E. \& StreckeR, M. R. 2005. Processes of oscillatory basin filling and excavation in a tectonically active orogen: Quebrada del Toro Basin, NW Argentina. Geological Society of America Bulletin 117(7), 887.

Howell, J. A., Schwarz, E., Spalletti, L. A. \& Veiga, G. D. 2005. The Neuquén Basin: an overview. In The Neuquén Basin, Argentina: A Case Study in Sequence Stratigraphy and Basin Dynamics (eds G. D. Veiga, L. A. Spalletti, J. A. Howell \& E. Schwarz), pp. 1-14. Geological Society of London, Special Publication no. 252.

Huyghe, D., Bonnel, C., Nivière, B., Fasentieux, B. \& HERVOUËT, Y. 2015. Neogene tectonostratigraphic history of the southern Neuquén basin $\left(39^{\circ}-40^{\circ} 30^{\prime} \mathrm{S}\right.$, Argentina): implications for foreland basin evolution. Basin Research 27(5), 613-35.

Kay, S. M., Burns, W. M., Copeland, P. \& Mancilla, O. 2006. Upper Cretaceous to Holocene magmatism and evidence for transient Miocene shallowing of the Andean subduction zone under the northern Neuquén Basin. In Evolution of an Andean Margin: A Tectonic and Magmatic View from the Andes to the Neuquén Basin $\left(35^{\circ}-39^{\circ} \mathrm{S}\right.$ lat) (eds S. M. Kay \& V. A. Ramos), pp. 19-60. Geological Society of America, Boulder, Special Paper no. 407, 19-60.

Kay, S. M., Ramos, V. A., Mrodozis, C. \& Sruoga, P. 1989. Late Paleozoic to Jurassic silicic magmatism at the Gondwana margin: analogy to the Middle Proterozoic in North America? Geology 17(4), 324-8.

KLEIMAN, L. E. \& JAPAS, M. S. 2009. The Choiyoi volcanic province at $34^{\circ} \mathrm{S}-36^{\circ} \mathrm{S}$ (San Rafael, Mendoza, Argentina): implications for the Late Palaeozoic evolution of the southwestern margin of Gondwana. Tectonophysics 473(3-4), 283-99.

Kozlowski, E., Manceda, R. \& Ramos, V. 1993. Estructura. In 12 Congreso Geológico Argentino Congreso de Exploración de Hidrocarburos. Beunos Aires, pp. 23556.

Kraemer, P., Silvestro, J., Achilli, F. \& Brinkworth, W. 2011. Kinematics of a hybrid thick-thin-skinned fold and thrust belt recorded in Neogene syntectonic wedgetop basins, Southern Central Andes between 35 and 36S, Malargue, Argentina. In Thrust Fault-Related Folding (eds K. McClay, J. Shaw \& J. Suppe), pp. 245-70. AAPG, Tulsa, Memoir no. 94.

Legarreta, L., Gulisano, C., Uliana, M. \& Ramos, V. 1993. Las secuencias sedimentarias jurásico-cretácicas. XII Congreso Geológico Argentino y II Congreso de Exploración de Hidrocarburos. Relatorio Geología y Recursos Naturales de Mendoza. Mendoza, 1(9), 87114.

Legarreta, L. \& UlianA, M. A. 1996. The Jurassic succession in west-central Argentina: stratal patterns, sequences and paleogeographic evolution. Palaeogeography, Palaeoclimatology, Palaeoecology 120(3), 30330.

Llambías, E. J., Quenardelle, S. \& Montenegro, T. 2003. The Choiyoi Group from central Argentina: a subalkaline transitional to alkaline association in the craton adjacent to the active margin of the Gondwana continent. Journal of South American Earth Sciences 16(4), 243-57.

MANCEDA, R. \& FigueroA, D. 1995. Inversion of the Mesozoic Neuquén rift in the Malargue fold and thrust belt, Mendoza, Argentina. In Petroleum Basins of South America (eds A. J. Tankard, R. Suarez Soruco \& H. J. Welsink), pp. 369-82. AAPG, Tulsa, Memoir no. 62.

Mescua, J. F. \& Giambiagi, L. B. 2012. Fault inversion vs. new thrust generation: A case study in the Malargüe fold-and-thrust belt, Andes of Argentina. Journal of Structural Geology 35, 51-63.

Mescua, J. F., Giambiagi, L. B., Tassara, A., Gimenez, M. \& RAMOS, V. A. 2014. Influence of pre-Andean history over Cenozoic foreland deformation: structural styles in the Malargue fold-and-thrust belt at $35^{\circ} \mathrm{S}$, Andes of Argentina. Geosphere 10(3), 585-609.

Morabito, E. G., GÖTZE, H.-J. \& RAMOS, V. A. 2011. Tertiary tectonics of the Patagonian Andes retro-arc area between $3815^{\prime}$ and $40 \mathrm{~S}$ latitude. Tectonophysics 499(1), $1-21$.

Mortimer, E., CARrapa, B., Coutand, I., Schoenbohm, L., Sobel, E. R., Sosa Gomez, J. \& STRECKer, M. R. 2007. Fragmentation of a foreland basin in response to out-of-sequence basement uplifts and structural reactivation: El Cajon-Campo del Arenal basin, NW Argentina. Geological Society of America Bulletin 119(5-6), 637-53.

Ramos, V. A., Cegarra, M. \& Cristallini, E. 1996. Cenozoic tectonics of the High Andes of west-central Argentina $\left(30-36^{\circ} \mathrm{S}\right.$ latitude). Tectonophysics 259(1-3), $185-200$.

RAmos, V., JoRdAn, T., Allmendinger, R. W., KAY, S. M., CORTÉS, J. \& PALMA, M. A. 1984. Chilenia: un terreno alóctono en la evolución paleozoica de los Andes Centrales. In 98 Congreso Geológico Argentino. Bariloche, Actas V. 2, pp. 84-106.

RAMOS, V. \& KAY, S. 2006. Overview of the tectonic evolution of the southern Central Andes of Mendoza and Neuquén (35-39 S latitude). Evolution of an Andean Margin: A Tectonic and Magmatic View from the Andes to the Neuquén Basin (35-39 $\mathrm{S}$ lat) (eds S. M. Kay \& V. A. Ramos), pp. 1-18. Geological Society of America, Boulder, Special Paper no. 407.

Ramos, V. A., Litvak, V. D., Folguera, A. \& Spagnuolo, M. 2014. An Andean tectonic cycle: from crustal thickening to extension in a thin crust $\left(34^{\circ}-37^{\circ} \mathrm{SL}\right)$. Geoscience Frontiers 5(3), 351-67.

Sepúlveda, E., Carpio, F., Regairaz, M., ZÁrate, M. \& ZANETTINI, J. 2000. Hoja Geológica 3569-II, San Rafael. Servicio Geológico Minero Argentino Boletín, 268.

SiKs, B. C. \& HorTON, B. K. 2011. Growth and fragmentation of the Andean foreland basin during eastward advance of fold-thrust deformation, Puna plateau and Eastern Cordillera, northern Argentina. Tectonics 30(6), doi: 10.1029/2011TC002944.

Silvestro, J., Kraemer, P., Achilli, F. \& Brinkworth, W. 2005. Evolución de las cuencas sinorogénicas de la Cordillera Principal entre $35^{\circ}-36^{\circ} \mathrm{S}$, Malargue. Revista de la Asociación Geológica Argentina 60(4), 627-43.

Strecker, M. R., Alonso, R., Bookhagen, B., CARraPA, B., Coutand, I., Hain, M. P., Hilley, G. E., Mortimer, E., SchoenBohm, L. \& Sobel, E. R. 2009. Does the topographic distribution of the central Andean Puna Plateau result from climatic or geodynamic processes? Geo$\log y 37(7), 643-6$. 
Strecker, M. R., Alonso, R. N., Bookhagen, B., Carrapa, B., Hilley, G. E., Sobel, E. R. \& Trauth, M. H. 2007. Tectonics and climate of the southern central Andes. In Annual Review of Earth and Planetary Sciences 35, 747-87.

Strecker, M. R., Hilley, G. E., Bookhagen, B. \& SoBEL, E. R. 2011. Structural, geomorphic, and depositional characteristics of contiguous and broken foreland basins: examples from the eastern flanks of the Central Andes in Bolivia and NW Argentina. In Tectonics of Sedimentary Basins (eds C. J. Busby \& A. Azor), pp. 508-21.Oxford: Blackwell Publishing Ltd.

Turienzo, M. M. \& Dimieri, L. V. 2005. Geometric and kinematic model for basement-involved backthrusting at Diamante River, southern Andes, Mendoza province, Argentina. Journal of South American Earth Sciences 19(2), 111-25.

Turienzo, M., Dimieri, L., Frisicale, C., Araujo, V. \& SÁNCHEZ, N. 2012. Cenozoic structural evolution of the Argentinean Andes at $34^{\circ} 40^{\prime} \mathrm{S}$ : a close relationship between thick and thin-skinned deformation. Andean Geology 39, 317-57.

Uliana, M., Biddle, K. T., Cerdan, J. \& TANKard, A. 1989. Mesozoic extension and the formation of Argentine sedimentary basins. In Extensional Tectonics and Stratigraphy of the North Atlantic Margin (eds A. J. Tankard \& H. R. Balkwill), pp. 599-613. AAPG, Tulsa, Memoir no. 46.

Vergani, G. D., TANKard, A. J., Belotti, H. J. \& WelsinK, H. J. 1995. Tectonic evolution and paleogeography of the Neuquén Basin, Argentina. In Petroleum Basins of South America (eds A. J. Tankard, R. Suarez Soruco \& H. J. Welsink), pp. 383-402. AAPG, Tulsa, Memoir no. 62.

YAgupsky, D. L., CRistallini, E. O., FAntín, J., VAlCARCE, G. Z., BotTESI, G. \& VARAdÉ, R. 2008. Oblique halfgraben inversion of the Mesozoic Neuquén Rift in the Malargue Fold and Thrust Belt, Mendoza, Argentina: new insights from analogue models. Journal of Structural Geology 30(7), 839-53. 